\title{
Investigations of the marine flora and fauna of the Islands of Palau
}

D. John Faulkner, ${ }^{a}$ David J. Newman $*^{*}{ }^{b}$ and Gordon M. Cragg ${ }^{b}$

a Scripps Oceanographic Institution, La Jolla, CA 92093, USA

${ }^{b}$ Natural Products Branch, Developmental Therapeutics Program, Division of Cancer Treatment and Diagnosis, NCI-Frederick, Frederick, MD 21702, USA

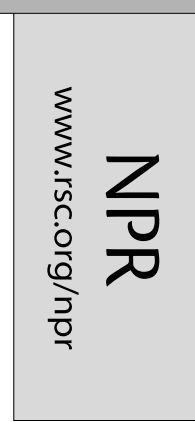

Received (in Cambridge, UK) 3rd September 2003

First published as an Advance Article on the web 23rd December 2003

Covering: 1970s to July 2003

The Islands of Palau have proven to be an excellent source of bioactive marine natural products primarily as a result of the systematic studies from the late 1970s by the research groups of Scheuer at the University of Hawaii, Faulkner at the Scripps Oceanographic Institution/University of California at San Diego, and Paul at the University of Guam. Their efforts were materially aided by the excellent facilities provided by the Government of Palau and for the last 10 years, those of the NCI's shallow water collection contractor, the Coral Reef Research Foundation. This review covers the structures and biological activities where noted, of the multitudinous marine-derived natural products isolated from the marine flora and fauna of this nation and demonstrates the enormous variety of novel structures elaborated by these organisms.

1 Introduction

2 The Islands of Palau

$\dagger$ Address for correspondence: Natural Products Branch, NCI, PO Box B, Frederick, MD 21702, USA. E-mail: dn22a@nih.gov
3 Why investigate Palauan waters?

3.1 Palau's microenvironments lead to increased biodiversity

$4 \quad$ A brief history of marine natural product research in Palau

D. John Faulkner, born in England in 1942, received his BSc and PhD degrees from Imperial College, London, where he studied synthetic organic chemistry under the guidance of Sir Derek Barton. He received postdoctoral training from R. B. Woodward at Harvard University and W. S. Johnson at Stanford University before joining the faculty of the Scripps Institution of Oceanography, University of California at San Diego, in 1968. Recognizing the need to do something more marine, he began a new career in marine natural products chemistry. When John died in November 2002 he was Professor of Marine Chemistry.

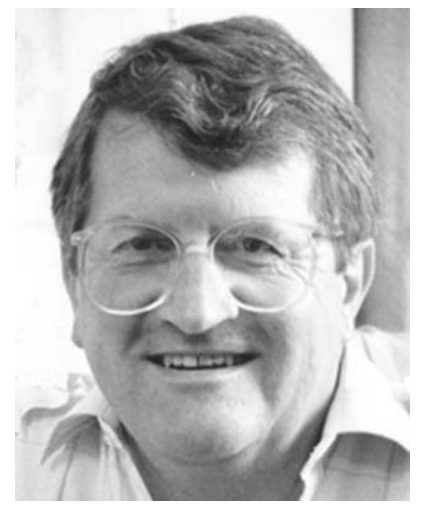

D. John Faulkner

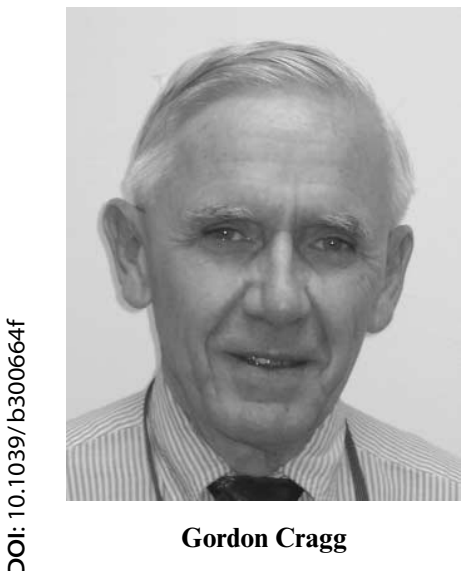

David Newman was born in Grays, Essex, UK, and received his D. Phil. in microbial chemistry from the University of Sussex in 1968. Following two years of postdoctoral studies on the structure of electron transport proteins at the University of Georgia, USA, he worked for a number of US-based pharmaceutical companies in natural products discovery programs, and joined the Natural Products Branch of the NCI in 1991. His scientific interests are in the discovery and history of novel natural products as drug leads in the anti-infective and cancer areas. In conjunction with Gordon Cragg, he has established collaborations between the National Cancer Institute and organizations in many countries promoting drug discovery from their natural resources. He is responsible for the marine and microbial collection programs of the NCI and in concert with Gordon Cragg (Chief, NPB), for the NCI's Open and Active Repository programs. He is both an UK Chartered Chemist and an UK Chartered Biologist and has published over 70 papers related to these interests.

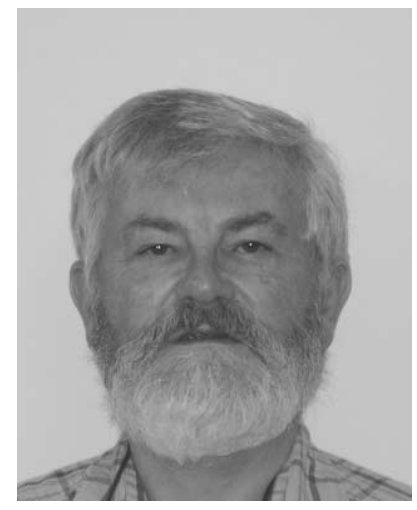

David Newman
Gordon Cragg was born in Cape Town, South Africa, and obtained his D. Phil. from Oxford University in organic chemistry in 1963. After two years of postdoctoral research in natural products chemistry at the University of California, Los Angeles, he returned to South Africa where he held several academic positions before returning to the United States in 1979 to join the Cancer Research Institute at Arizona State University. In 1985, he moved to the National Cancer Institute in Bethesda, Maryland, and was appointed Chief of the Natural Products Branch in 1989. His major interests lie in the discovery of novel natural product agents for the treatment of cancer and AIDS. In 1991 he was awarded the National Institutes of Health Merit Award for his contributions to the development of the anticancer drug, taxol, and in 1998 he was elected President of the American Society of Pharmacognosy. He has established collaborations between the National Cancer Institute and organizations in many countries promoting drug discovery from their natural resources. He has published over 100 papers related to these interests. 
5 Overview of therapeutic areas

5.1 Anti-inflammatory compounds

5.2 Studies of anti-cancer agents

5.3 Contributions to cellular biology

6 Studies on the role of chemistry in symbiosis

7 Organisms (organized by Phylum, Class, Order and

alphabetized by Genus/species)

7.1 Chordata, Ascidacea, Enterogona

7.2 Cnidaria, Alcyonaria, Alcyonacea

7.3 Cyanophycota, Cyanophyceae, Nostocales

7.4 Miscellaneous bacteria/fungi

7.5 Mollusca

7.6 Mollusca, Gastropoda, Nudibranchia

7.7 Porifera

7.8 Porifera, Demospongiae, Agelascida

7.9 Porifera, Demospongiae, Astrophorida

7.10 Porifera, Demospongiae, Axinellida

7.11 Porifera, Demospongiae, Dendroceratida

7.12 Porifera, Demospongiae, Dictyoceratida

7.13 Porifera, Demospongiae, Halichondrida

7.14 Porifera, Demospongiae, Haplosclerida

7.15 Porifera, Demospongiae, Homosclerophorida

7.16 Porifera, Demospongiae, Lithistida

7.17 Porifera, Demospongiae, Petrosida

7.18 Porifera, Demospongiae, Poecilosclerida

7.19 Porifera, Demospongiae, Verongida

8 Conclusion

9 References

\section{Introduction}

With the untimely death of John Faulkner in November of 2002, following complications from cardiac surgery, the marine natural products world in particular and chemistry in general, lost one of its greatest exponents of the arcane art of structural determination of the extremely complex and unusual compounds elaborated by marine-dwelling organisms.

John published approximately 300 scientific papers in the field of marine natural products chemistry and related topics and was instrumental, together with his colleagues at The Scripps Institute of Oceanography, where he spent all of his time after post-doctoral studies at Harvard and Stanford, in demonstrating the exquisite chemistry that marine organisms of all types elaborate as mechanisms of attack and defence.

Although not able to dive due to medical restrictions, he was an avid snorkeller and collector and was able to gather around him a large number of very talented graduate students, postdoctoral fellows, collaborators (in particular, Bob Jacobs at the University of California, Santa Barbara) and colleagues who collected marine organisms in a variety of places in the Pacific, but notably in the Islands of Palau.

This review is based on a report that John initially started with a Palauan undergraduate student, Jason Kurtei, who spent a few months with John as part of a Scripps Undergraduate Research Fellowship Program in La Jolla in 1997, and was then further developed by John but never published.

With the express consent of Meryl Faulkner, John's widow, we have taken his original manuscript, extended it to July of 2003, shortened some of the entries, extended others, and then updated and included organisms that John did not cover in the original. We have tried to keep the same general format that was used in the original report, a short series of history and highlights and then what is effectively an annotated bibliography organized by phylum/organism, where structures are shown and biological activities are reported and commented on where necessary.

We (D. J. N. \& G. M. C.) should emphasize from herein that any errors are ours, not his.

\section{The Islands of Palau}

The Islands of Palau (also known as the Republic of Belau) are found between $7^{\circ}$ and $8^{\circ} \mathrm{N}$ Latitude and $133^{\circ}$ to $134^{\circ} \mathrm{E}$ Longitude (cf. Fig. 1). Originally known as the Western Caroline Islands, following their discovery by Spain in the 1500s, there was no formal incorporation into a "Spanish Empire" until 1885 , when the Pope confirmed Spain's rights to the islands. In the 300 years prior to this, both English and German seafarers had established first trading posts and then coaling stations. Following the Spanish-American war, in 1899 the Carolines were sold to Imperial Germany. In 1914, when Japan declared war on Germany, the German possessions in Micronesia came under Japanese control and then they continued under Japanese control as a League of Nations mandate, finally becoming fortified islands until the end of WWII. Following WWII and a very convoluted series of associations with Micronesia and the USA, Palau became an independent nation on October $1^{\text {st }}, 1994$ as the Republic of Belau. For further information, the reader should consult the excellent history of Palau by Mandy Etpison, the daughter-in-law of the third president of Belau. ${ }^{1}$

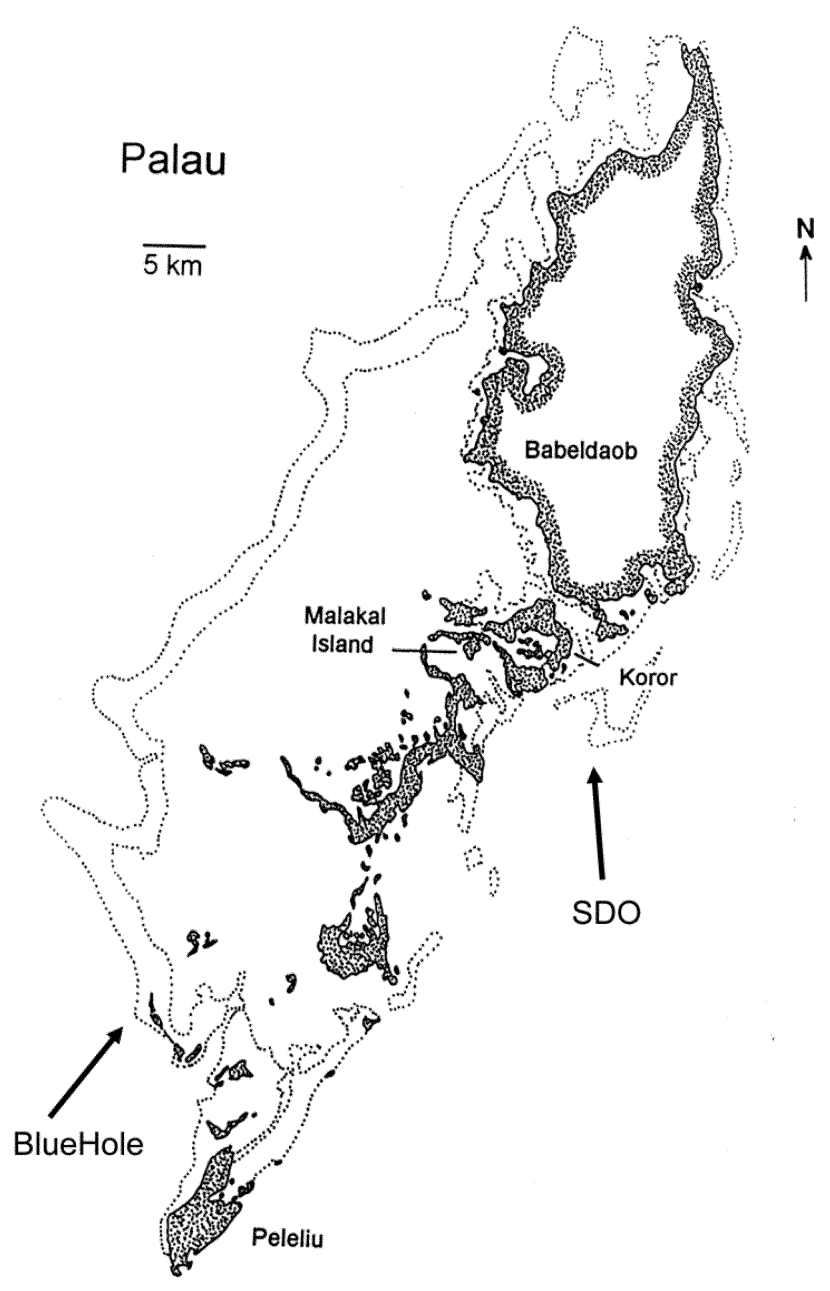

$\mathrm{SDO}=$ Short Drop Off; $0715.96 \mathrm{~N}, 13431.28 \mathrm{E}$

Blue Hole; 0708.10 N, $13413.90 \mathrm{E}$

Fig. 1 The Islands of Palau (pen and ink drawing courtesy of Dr and Mrs Patrick Colin, CRRF).

Over the early part of the $20^{\text {th }}$ Century, a variety of German and Japanese scientists had begun to investigate the flora and fauna of the islands, but it was really with the advent of SCUBA apparatus and the establishment of a relatively stable form of government after the 1960s that marine biologists and 
marine natural product chemists began to systematically study the fauna of these islands, and from 1979, John was one of these investigators.

\section{Why investigate Palauan waters?}

The scientific rationale is quite simple. Palau has the greatest diversity of marine habitats and organisms that can be packed into such a small geographical area. Although this sentence was originally written in 1997, the publication in 2002 by Hooper et al., confirmed this comment as in their report, the authors demonstrated that Palau, like the Great Barrier Reef in Australia, is a "biodiversity hotspot" with over $73 \%$ of the reported sponges demonstrating endemism when compared with other areas of the Pacific. ${ }^{2}$

Add to this the availability of excellent diving resources, freezer facilities, and most of all, knowledgeable guides and you have an almost perfect location for the collection of marine specimens. Palau is served by reliable and frequent air transportation so that samples can be transported back to major research facilities in good condition. The laboratories of the Marine Mariculture Demonstration Center (MMDC) in the past and now those at the Coral Reef Research Foundation (CRRF, the current Collection Contractor for the NCI's shallow water collection programme) have allowed researchers to do more than just collect specimens - they can get their research started while still in a position to refine their collections for later study.

\subsection{Palau's microenvironments lead to increased biodiversity}

Most tourists visit Palau to dive along the precipitous reef walls that provide spectacular vistas of brightly colored fishes and the occasional thrill of encountering sharks, rays or turtles. While they are vaguely aware of brightly colored invertebrates packed along the vertical surfaces of these underwater cliffs, they seldom stop to wonder at the numbers of different plants and invertebrates to be found and give no thought at all to the distribution of the sessile inhabitants of the reef. To most divers, invertebrates are the background against which fish are photographed.

Scientists see this panorama in a very different light. They notice that the community of sessile invertebrates changes somewhat with depth but often more depending on exposure to direct sunlight. The inhabitants of a pass or channel between reefs are different from those on the outer or inner faces of a reef due to changes in water flow and turbidity. Caves and tunnels provide a different set of inhabitants, which is often comprised of animals that would normally exist at much greater depths. Mud flats, mangrove swamps, shallow reefs, coral rubble and even manmade docks all provide different contributions to the overall marine biodiversity of an area. When you add to this catalog of microenvironments and their occupants, the unique communities that are found in the marine lakes of Palau, you have a paradise for scientists seeking a broad diversity of marine invertebrates. Palau, which is located not far from the presumed center of coral reef biodiversity, appears to have captured more than its fair share of invertebrate species, in particular, sponges. ${ }^{2}$

\section{A brief history of marine natural product research in Palau}

Marine natural product research started in the 1950s largely as a result of the availability of SCUBA but it did not really become a separate scientific discipline until about 1970, when it became an integral part of the search for new pharmaceutical agents. The search for "Drugs from the Sea" has been and still is the driving force behind the funding of research on the chemistry of marine organisms. To a lesser extent, funding agencies have also supported basic research on the chemical ecology of marine ecosystems, which concentrates on demonstrating how marine plants and invertebrates have benefited from producing toxic or deterrent chemicals.

As far as we have been able to determine, the first groups to systematically collect marine organisms in Palau for chemical studies were those of Paul Scheuer from Hawaii, the Suntory Institute from Japan, and the Faulkner group from Scripps, who were housed at MMDC in the late 1970s and early 1980s. In 1979, Bill Fenical (from Scripps) led a research expedition to Palau aboard the R/V Alpha Helix but the collection of organisms was not the major activity of the expedition. The early studies led to the discovery of a number of anti-inflammatory agents, the most promising of which was manoalide. The US National Cancer Institute has had a long association with Palau, indirectly as a result of Bob Pettit's (Arizona State University) collections in the 1980s and now directly, as they support the professional collecting activities of the Coral Reef Research Foundation, who are based in Koror. Japanese scientists and ships have visited Palau quite frequently over the past 20 years but their activities have resulted in relatively few publications. For the past fifteen years, the majority of US supported natural product research from the waters of Palau has been reported by Paul Scheuer from Hawaii, Valerie Paul from Guam, and John Faulkner from Scripps.

\section{Overview of therapeutic areas}

\subsection{Anti-inflammatory compounds}

Collections from Palau played a key role in the US government's Sea Grant funded research to discover new antiinflammatory agents from marine organisms. In particular, the discovery that manoalide $\mathbf{1 2 3}$ from the sponge Luffariella variabilis inhibited the enzyme phospholipase $\mathrm{A}_{2}\left(\mathrm{PLA}_{2}\right)$, which plays a key role in inflammatory conditions such as arthritis, allowed researchers to study the role of $\mathrm{PLA}_{2}$ in inflammation as well as providing the stimulus for further research to discover new agents. Despite initial expectations and hopes, manoalide was eventually dropped as a drug candidate but only after human trials had proved it to be ineffective, though there are still derivatives in preclinical and clinical studies.

Manoalide is a major constituent of the sponge Luffariella variabilis that is one of the most common sponges on the reefs around Palau. The structure of manoalide was published in 1980 by Paul Scheuer's group, but without any biological activity testing. In the meantime Faulkner's group had isolated manoalide and supplied it to Robert Jacobs at the University of California, Santa Barbara, where it was first observed to be a pain-killer and was subsequently found to interrupt the biochemical sequence responsible for pain caused by inflammatory conditions such as insect stings, arthritis, burns, etc. In animal models, it was more effective than the best anti-inflammatory agents then available.

Since it was a novel agent, why did it not progress further? There were several reasons, some scientific and others more practical. The best scientific reason was that manoalide did not interact with the enzyme $\mathrm{PLA}_{2}$ in the usual manner. Rather than directly inhibiting the enzyme by binding at the active site, thus blocking its enzymatic activity, manoalide reacted with the surface of the enzyme and prevented the enzyme from moving across membranes. Thus it was neither a direct competitor nor an allosteric inhibitor. It also had other side effects as PLA $_{2}$ was not the only enzyme that it bound to the surface of. Thus it was not an ideal drug candidate. In addition, since Scheuer had published the structure before any biological activity was identified, the natural product could not be patented, though a "use patent" could be awarded.

Allergan Pharmaceuticals embarked on a program to synthesize compounds that resembled manoalide, in the hope that a synthetic compound would be better than manoalide and to a certain extent they succeeded. As part of their development strategy, Allergan decided to perform a clinical 
trial to determine whether manoalide could be used topically for the treatment of psoriasis but that trial was not successful. Although the unsuccessful clinical trial sealed the fate of manoalide as a pharmaceutical, it has continued to be used as a biochemical reagent to block the action of phospholipase $A_{2}$ and is essentially a standard reagent for this purpose.

A second anti-inflammatory agent resulted from a collaboration between academic scientists and a small biotechnology start-up company, OsteoArthritis Sciences Inc., and was again sponsored by Sea Grant. It was found that debromohymenialdisine $(\mathrm{DBH}) \mathbf{1 6 4}$, which is a major metabolite of the sponge Stylotella aurantium, which is very common in the shallow waters of Palau, could be successfully used to treat osteoarthritis in laboratory animals. Progress in the development of DBH appeared to be going very well when the company was suddenly closed down.

One problem in the further development of this agent is the justifiable position by the University of California that any developer must accept an obligation to share benefits arising from the marketing of $\mathrm{DBH}$ with the country of origin, which in this case is Palau. This is also the case with any agent identified by investigators using any of the materials collected by CRRF as part of their NCI collection contract. DBH has been reported from other sources and under the $\mathrm{NCI}$ programme, some benefit would have to be paid even if made by total synthesis. The ultimate fate of this agent/patent is unknown.

Although manoalide and DBH represented the best opportunities to date for development of a pharmaceutical product from Palauan marine specimens, they are by no means the only chemicals to be studied in depth by pharmacologists and molecular biologists. Palauan specimens have provided more than fifty compounds that have been studied to some level or another as potential anti-inflammatory agents by academic and industrial pharmacologists. The contributions of these studies to basic science have been extremely valuable and cannot be overlooked.

\subsection{Studies of anti-cancer agents}

Many of the metabolites reported from Palauan specimens are cytotoxic in as much as they kill cancer cells in tissue culture (in vitro), but very few of these compounds have proved successful in animal models (in vivo). The underlying problem is that many cytotoxins are toxic both to normal cells and cancer cells and would therefore be as damaging to the patient as to the patient's tumour. Therefore, scientists seek compounds that show selective toxicity toward the cancer cells. It is important when reading the annotated bibliography to differentiate between compounds that show real promise for the treatment of cancer (in vivo activity) and those that are reported as cytotoxic (in vitro activity).

There are compounds from sponges collected in Palau that have undergone preliminary in vivo testing in animal models but, at present, no compounds from Palauan marine organisms have been/are in clinical trials as anti-cancer agents, though the number of novel structures being reported, particularly from cyanophytes (see below in the annotated bibliography), bodes well for the future.

\subsection{Contributions to cellular biology}

During the past few years, many cellular biologists have realized the value of marine natural products as biological probes that can be used to inhibit specific enzymes and thereby discover the inner workings of cells. They have gone from using pure compounds that were (sometimes) identified in pharmaceutical screens to the testing of extracts of marine organisms in assays developed to study specific organelles or processes that are essential to cellular organization. Two successes have been recorded in this area, ilimaquinone 98 and adociasulfate-2 170.
Ilimaquinone, which was first isolated from the Palauan sponge Hippospongia metachromia by Paul Scheuer's group, causes the Golgi apparatus to break down into small particles in the same manner that it does during cell division. Collaborative research between the Faulkner laboratory at Scripps and the group of Vivek Malhotra at UCSD Biology Department has led to a better understanding of how the Golgi maintains its essential 3-dimensional structure within the cell.

Collaboration between the Faulkner laboratory and the group of Larry Goldstein at the UCSD Pharmacology Department led to the discovery of the first inhibitor of motor proteins, which are used to transport peptides along a network of microtubules from the Golgi to their final destination. The inhibitor, adociasulfate-2 (AS-2), was obtained from a Haliclona (aka Adocia) species of sponge that was collected in Palau.

\section{Studies on the role of chemistry in symbiosis}

This is a new area of study that has clearly benefited from the ability to do laboratory research in Palau. Carole Bewley was able to separate symbiotic microorganisms from sponge cells while in Palau. ${ }^{3}$ On her return to Scripps, she performed chemical analyses on the cell fractions and was able to demonstrate that the biologically active constituents of the sponge Theonella swinhoei were in fact produced by symbiotic microorganisms. Further research by Eric Schmidt has resulted in identification of one of the symbiotic microbes using DNA analysis after demonstrating that the microbe can grow in medium supplemented with a piece of the host sponge but not in pure culture medium (pers. comm.). Further work by Christine Salomon on the localization of dercitamide ${ }^{4}$ and cyclic peptides $^{5}$ are also examples of this approach. These and others are discussed under the specific organism headings below. This essentially new approach to the problem of finding out how and why symbiotic associations occur could not have been contemplated without the proximity of laboratory facilities to the collecting site.

\section{Organisms (organized by Phylum, Class, Order and alphabetized by Genus/species)}

In these subsequent sections, the common names of most of the dive sites, their Palauan names and the GPS coordinates are shown in Fig. 1 (the Islands themselves), Fig. 2 (common dive sites, frequently on the Eastern side of the larger islands) and in Table 1. All geographic information and maps were provided by Dr and Mrs Patrick Colin of the Coral Reef Research Foundation.

\subsection{Chordata, Ascidacea, Enterogona}

\section{Aplidium longithorax}

This tunicate was collected in Palau in 1994, identified by Dr F. Monniot, Museum National d'Histoire Naturelle, Paris and a voucher specimen was deposited at the University of Oklahoma (\#1-PA-94).

Chemistry/bioactivity: longithorols A 1 and B 2 were isolated as their pentaacetates because of stability problems and are the first examples of hydroquinones from this chemical class. They are easily converted to the corresponding quinones by exposure to air and thus no bioactivities have been reported for longithorols $\mathrm{A}$ and $\mathrm{B}^{6}$

\section{Didemnum rubeum}

The red encrusting colonial ascidian Didemnum rubeum, collected from the walls of Lighthouse Channel, was identified by Dr F. Monniot and has been deposited at the Museum National d'Histoire Naturelle (registry \# MN1 N A2 Did C376). 
Table 1 Selected dive sites in Palau: their proper Palauan names, the names used in this review and GPS coordinates

\begin{tabular}{|c|c|c|c|c|}
\hline Site & Proper Palauan name & Review names & Latitude & Longitude \\
\hline 1 & Lighthouse Channel (Toachel ra Kesebekuu) & Lighthouse Channel & $0717.03 \mathrm{~N}$ & $13427.82 \mathrm{E}$ \\
\hline 2 & Ngel Channel (Toachel ra Ngel) & Ngell Channel & $0718.48 \mathrm{~N}$ & $13428.12 \mathrm{E}$ \\
\hline 3 & Short Drop Off (Uchelbeluu Reef) & Short Drop Off or Agulpelu Reef & $0715.96 \mathrm{~N}$ & $13431.28 \mathrm{E}$ \\
\hline 4 & Bab el Lukes Reef & Babelukes Reef & $0717.58 \mathrm{~N}$ & $13430.59 \mathrm{E}$ \\
\hline 5 & Goby Lake & Big Goby Marine Lake & $0718.76 \mathrm{~N}$ & $13430.10 \mathrm{E}$ \\
\hline 6 & Iwayama Bay & Iwayama Bay, Arumizu Bay, Nikko Bay & $0719.01 \mathrm{~N}$ & $13429.83 \mathrm{E}$ \\
\hline 7 & Hotel Nikko Dock & Hotel Nikko Dock & $0720.25 \mathrm{~N}$ & $13429.60 \mathrm{E}$ \\
\hline 8 & Kaibakku Lake & Kaibakku Marine Lake & $0719.47 \mathrm{~N}$ & $13429.42 \mathrm{E}$ \\
\hline 9 & Turtle Island (Ucheliungs) & Turtle Island & $0718.56 \mathrm{~N}$ & $13430.10 \mathrm{E}$ \\
\hline 10 & Risong Lake & Risong Marine Lake & $0718.74 \mathrm{~N}$ & $13428.04 \mathrm{E}$ \\
\hline 11 & Siaes Tunnel & Siaes Tunnel & $0718.76 \mathrm{~N}$ & $13413.50 \mathrm{E}$ \\
\hline 12 & Ulong Channel (Ngerumekaul) & Ulong Channel (Aulong Channel) & $0716.99 \mathrm{~N}$ & $13414.71 \mathrm{E}$ \\
\hline 13 & Ngemelis Drop Off & Ngemelis Drop Off & $0706.95 \mathrm{~N}$ & $13414.44 \mathrm{E}$ \\
\hline 14 & Wonder Channel & Wonder Channel & $0710.83 \mathrm{~N}$ & $13421.67 \mathrm{E}$ \\
\hline 15 & Ngeruktabel Island & Urukthapel Island & none ${ }^{a}$ & none \\
\hline 16 & Ngeruktabel Lake & Ngeruktebel Marine Lake & $0716.80 \mathrm{~N}$ & $13425.92 \mathrm{E}$ \\
\hline 17 & Beduliaes & Peduliaes Headland & $0720.20 \mathrm{~N}$ & $13425.70 \mathrm{E}$ \\
\hline
\end{tabular}

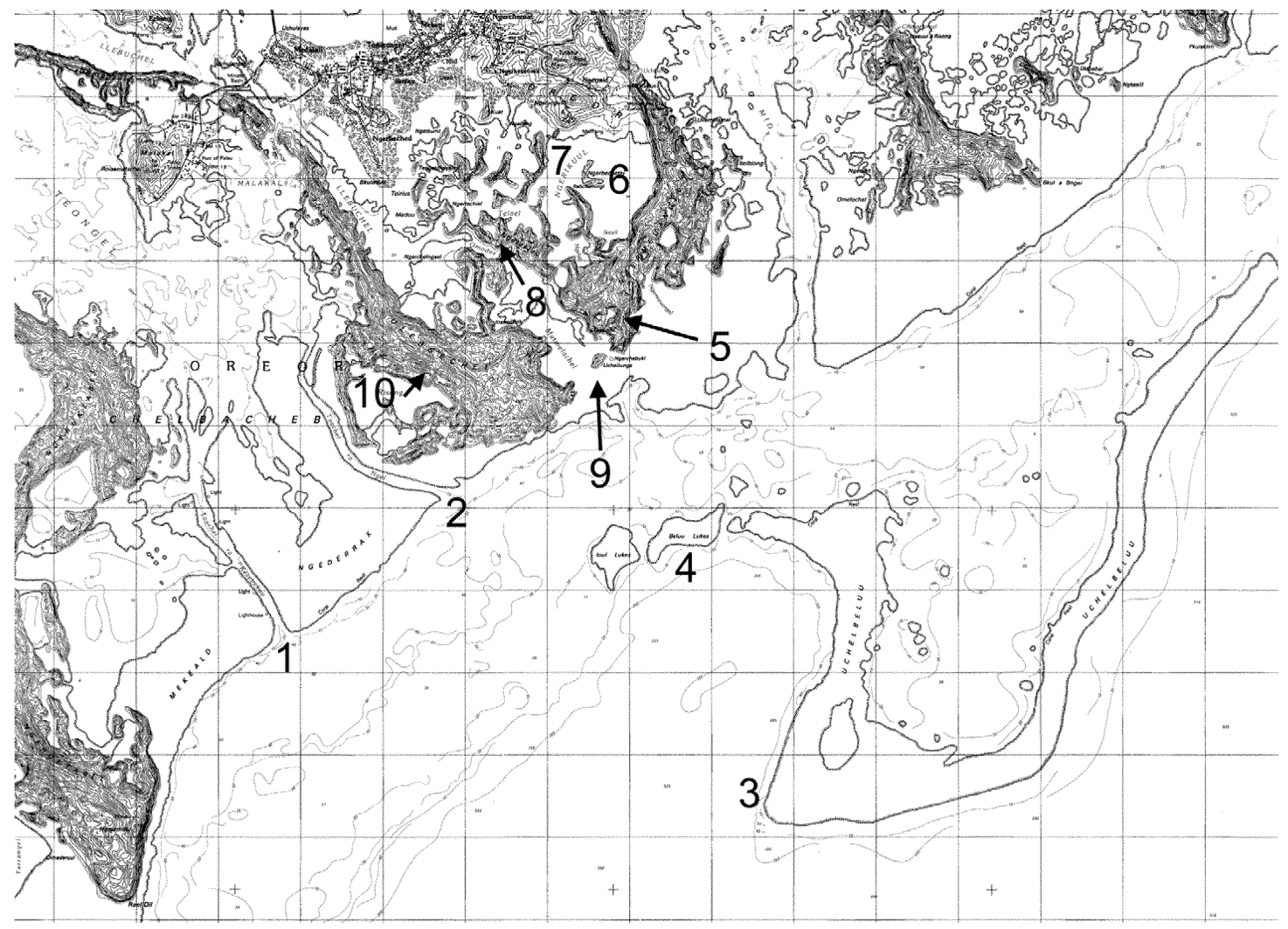

Fig. 2 Selected dive sites in Palau.

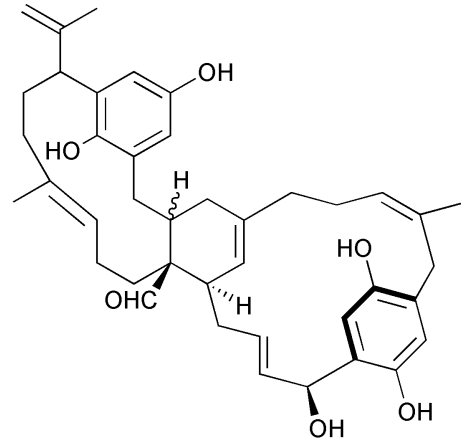

1

Chemistry/bioactivity: Didemnum rubeum contained large amounts of 3,5-diiodo-4-methoxyphenyl-ethylamine 3 and plakinidine D 4. $^{7}$ Plakinidine D 4 was also obtained from an

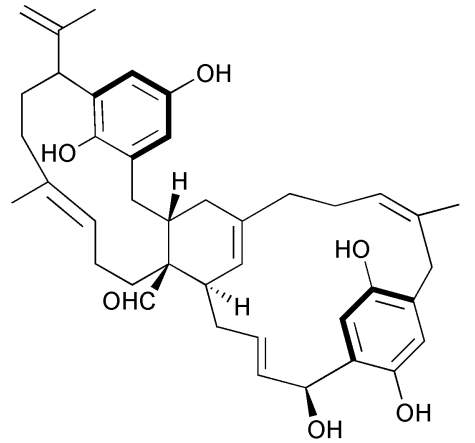

2

Indonesian Didemnum sp. ${ }^{7}$ and the isolation of both $\mathbf{3}$ and $\mathbf{4}$ was simultaneously reported from the same species by Ford and Davidson ${ }^{8}$ from samples collected in the Marshall Islands. The 
only reported activity was an in vitro study showing cytotoxicity of 4 against HCT-116 at $5 \mu \mathrm{g} \mathrm{mL}^{-1}$.<smiles>COc1c(I)cc(CCN)cc1I</smiles>

3

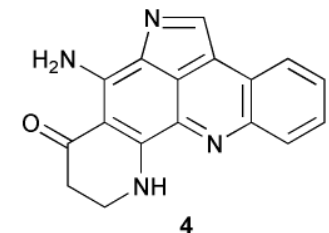

4

\section{Didemnum sp}

A magenta colored colonial tunicate was found in a bay off Ngell Channel on Auluptagel and collections were made in 1979 and 1993. Currently, it is still an undescribed species (F. Monniot, pers. comm.) with a voucher specimen deposited in the Museum National d'Histoire Naturelle, Paris (registration \# MNHN Az DidC 266).

Chemistry/bioactivity: the first sample to be studied had been stored in methanol for about 10 years and when extracted gave two terpenoids, didemnaketals A and B 5. ${ }^{9}$ However, when a freshly collected specimen was investigated, only didemnaketal C 6 was isolated, which led to the conclusion that didemnaketals $\mathrm{A}$ and $\mathrm{B}$ were artifacts of the storage and extraction processes. ${ }^{10}$ The full stereochemistry of didemnaketal $\mathrm{C} \mathbf{6}$ has not yet been elucidated. Didemnaketals A and B inhibited the enzyme, HIV-1 protease ${ }^{9}$ and though several protease inhibitors are now available, the didemnaketals were not considered drug candidates because the ester groups are too easily hydrolyzed. However, although these compounds may well be isolation artifacts, their basic structural motif has been used as the starting point for simplified analogues that appear to inhibit HIV protease by an unusual mechanism, inhibition of dimerization of the inactive HIV monomers to give the active dimeric HIV protease albeit with the most active, 7 having a high in vitro $K_{\mathrm{i}}$ of $2.1 \mu \mathrm{M}^{11}$

\section{Eudistoma gilboverde}

This particular example of Eudistoma gilboverde was collected in the Siaes Tunnel by the NCI collection contractor, the Coral Reef Research Foundation, identified by Dr F. Monniot and a voucher was deposited at the Smithsonian Institution (\# 0CDN5058).

Chemistry/bioactivity: the organic extract of this ascidian was cytotoxic in the NCI 60 cell line panel and from this material, three new $\beta$-carboline alkaloids, 2-methyleudistomin D 8, 2-methyleudistomin J 9 and 14-methyleudistomin C 10 were isolated and identified by following their bioactivities against four cell lines. In addition to these new derivatives, six known eudistomins were also found, eudistomins C, D, E, J, K and L. Of the three new compounds, 14-methyleudistomin C exhibited the most potent in vitro activity, with $\mathrm{IC}_{50}$ values of $<1 \mu \mathrm{g} \mathrm{mL}{ }^{-1}$ against the test lines. ${ }^{12}$<smiles>[R]c1cc2[nH]c3c[n+](C)ccc3c2c([R])c1O</smiles>

8; $\mathrm{R}_{1}=\mathrm{Br}, \mathrm{R}_{2}=\mathrm{H}$

9; $R_{1}=H, R_{2}=B r$

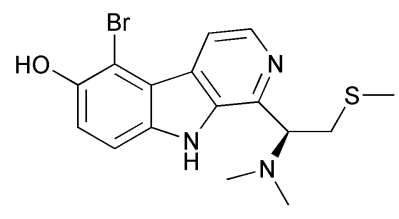

10

\section{Lissoclinum patella}

The colonial ascidian Lissoclinum patella is commonly found in shallow water around Koror and elsewhere in Palau. It is generally described as being off-white with green striations that are caused by the presence of the symbiotic cyanobacterium, Prochloron sp., which has been studied extensively by Lewin and colleagues and recently, some evidence of a form of protective symbiosis between the ascidian and the Prochloron sp. has been demonstrated in the case of the Palauan organism by workers with the Japanese Marine Biotechnology Institute, who reported a "sunscreen effect" by mycosporine-like amino acids produced by the ascidian. ${ }^{13}$

Chemistry/bioactivity: Palauan specimens of $L$. patella are the source of ulicyclamide $\mathbf{1 1}$ and ulithiacyclamide $\mathbf{1 2},{ }^{14}$ patellamides A-C 13-15, ${ }^{15}$ preulithicyclamide 16, ${ }^{16}$ and several other closely related cyclic peptides. ${ }^{17,18}$ Most of the cyclic peptides are cytotoxic to various degrees with ulithiacyclamide $\mathbf{1 2}$ being the most potent. ${ }^{15}$ This compound also inhibits the Macrophage Scavenger Receptor, resulting in inhibition of the progress of atherosclerotic lesions, with an $\mathrm{IC}_{50}$ of $98 \mathrm{nM}{ }^{16}$

Cellular location studies: there had been considerable discussion in the literature as to whether these peptides were produced (at least in part) by the cyanophyte but variable results were reported. In 2002, Salomon and Faulkner, using the on-site facilities of the Coral Reef Research Foundation on Koror, were able to carefully dissect examples of $L$. patella and subsequently show that the peptides were distributed through-

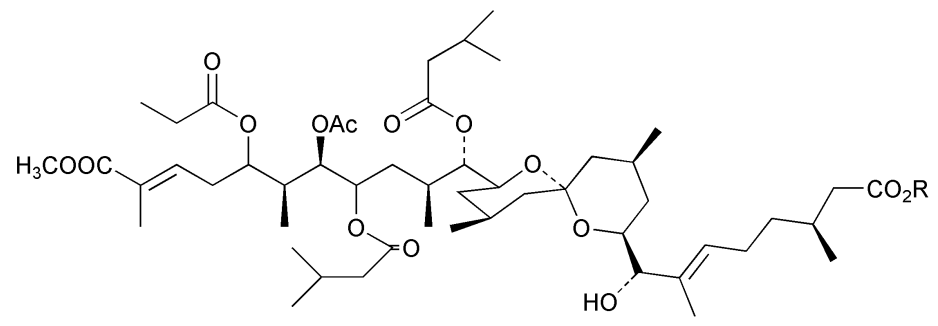

5; $\mathrm{R}=\mathrm{CH}_{3}$

6; $\mathrm{R}=\mathrm{CH}_{2} \mathrm{CH}_{2} \mathrm{SO}_{3} \mathrm{Na}$

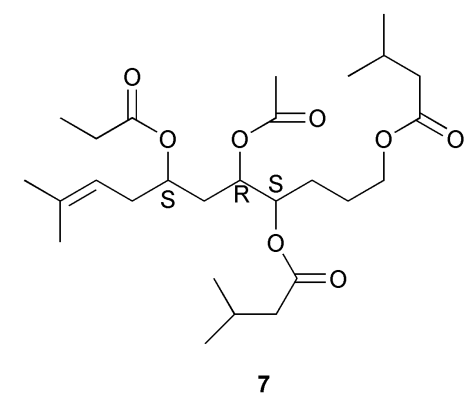


<smiles>CCC(C)C1NC(=O)C(N=C2NC(=O)c3csc(n3)[C@H](C)NC(Cc3ccccc3)C(=O)N3CCC[C@@H]23)N1c1nc(C(=O)N[C@@H](C)c2csc(C)n2)cs1</smiles>

11

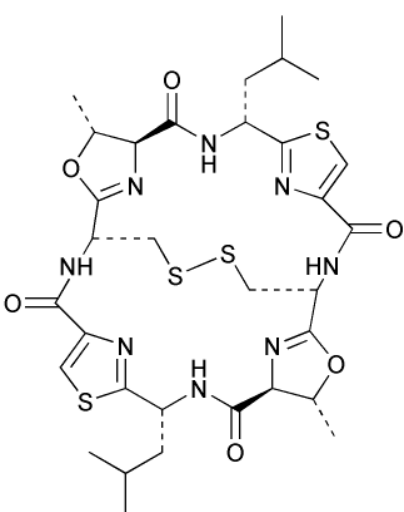

12 out the tunic of the ascidian and were not found in any detectable quantity in intact Prochloron cells. ${ }^{5}$

These findings do not demonstrate the source of the peptides but do open up a series of questions as to how peptides could migrate from the cyanophyte into the lower tunic.

\section{Lissoclinum voeltzkowi}

This encrusting grey ascidian was collected from sea grass blades in shallow waters in the lagoon at Palau. The identification was by Dr F. Monniot and a voucher specimen has been deposited at the Museum National d'Histoire Naturelle in Paris (registry \# MNHN A2 Lis 138).

Chemistry/bioactivity: an unusual spiroketal, lissoketal 17, was isolated from this organism but no bioactivity data was reported. ${ }^{19}$

\subsection{Cnidaria, Alcyonaria, Alcyonacea}

\section{Lobophytum cf. pauciflorum}

This soft coral, Lobophytum cf. pauciflorum was collected at Short Drop Off in 1995 and a voucher specimen was deposited at SIO (collection \# 95-095).

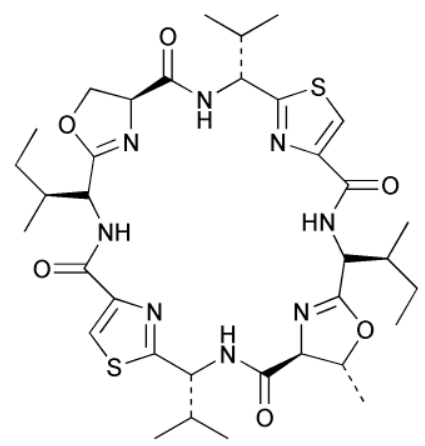

13

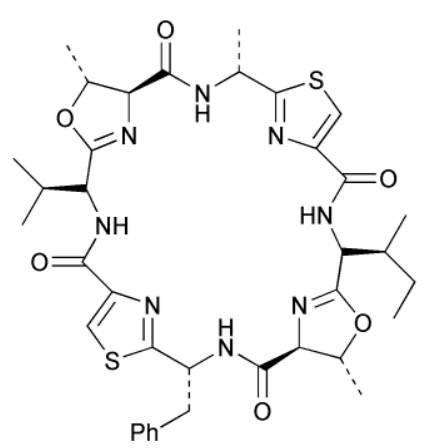

15<smiles>O=C1CC(CCO)OC12CC=CCO2</smiles>

17

Chemistry/bioactivity: two new sterols, $11 \alpha$-acetoxy-24methylenecholesta- $3 \beta, 5 \alpha, 6 \beta$-triol 18 and $11 \alpha$-acetoxy- $24 R$ methylcholesta-3 $\beta, 5 \alpha, 6 \beta$-triol were isolated from the soft coral. No bioactivity data was reported by the authors. ${ }^{20}$<smiles>C=C(CCC(C)[C@H]1CCC2C3C[C@H](O)[C@@]4(O)CC(O)CC[C@]4(C)C3C(OC(C)=O)C[C@@]21C)C(C)C</smiles>

\section{Sinularia inelegans}

This specimen of the soft coral S. inelegans (PSC-217) was collected during the 1979 cruise of the R/V Alpha Helix.

Chemistry/bioactivity: $S$. inelegans contained two new norcembrane diterpenes 19 and 20 with the structure of 19 being determined by X-ray crystallography. No bioactivity data was reported by the authors. ${ }^{21}$

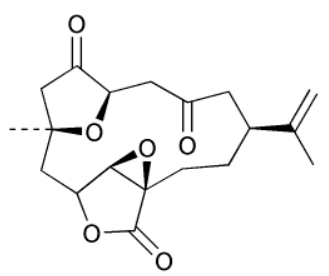

19<smiles></smiles>

14

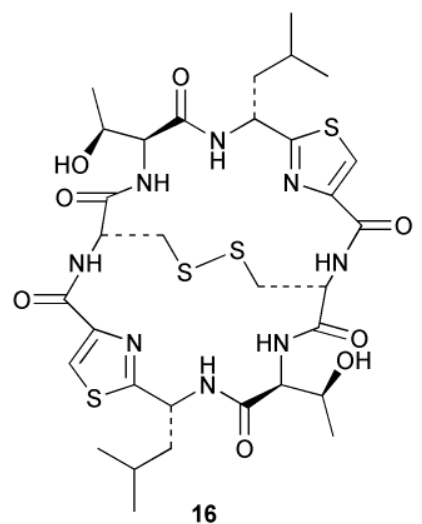




\section{Sinularia numerosa}

As with $S$. inelegans, this specimen of the soft coral $S$. numerosa (PSC-187) was also collected during the 1979 cruise of the R/V Alpha Helix.

Chemistry/bioactivity: $S$. numerosa contained one new norcembrane diterpene $\mathbf{2 1}$ and the known norcembenolide $\mathbf{2 2}{ }^{22}$ As with 19 above, the structure of $\mathbf{2 1}$ was determined by X-ray crystallography. ${ }^{21}$

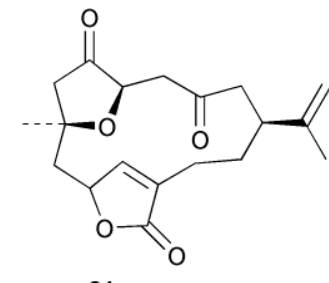

21

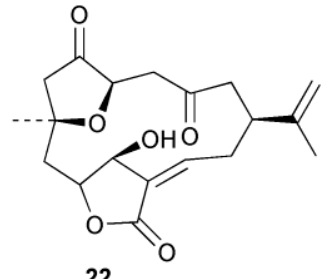

\section{Sinularia querciformis}

This specimen of the soft coral S. querciformis (PSC-30) was another collected during the 1979 cruise of the R/V Alpha Helix.

Chemistry/bioactivity: $S$. querciformis contained the known norcembenolide 22 and one new norcembrane diterpene $\mathbf{2 3}$, but no bioactivity information was presented. ${ }^{21}$

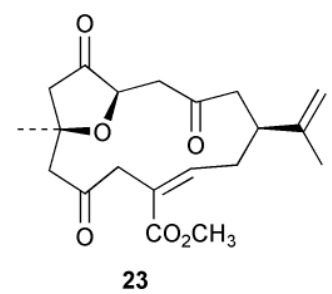

\section{Sinularia sp. A}

As above, this specimen of a new soft coral, Sinularia $\mathrm{sp}$. (PSC-159) was also collected during the 1979 cruise of the R/V Alpha Helix.

Chemistry/bioactivity: the Sinularia sp. contained the new norcembrane diterpene $\mathbf{2 1}$ but no bioactivity information was presented. $^{21}$

\section{Sinularia sp. B}

This unidentified specimen of Sinularia sp. was collected at Aulong Island in 1991.

Chemistry/bioactivity: this Sinularia sp. contained $13 \alpha-$ hydroxypukalide $\mathbf{2 4}$, first isolated from $S$. polydactyla by Bowden et al. ${ }^{23}$ and the known ${ }^{24}$ furanosesquiterpene acid $25 .{ }^{25}$ $13 \alpha$-hydroxypukalide was reported to inhibit settlement of the blue mussel Mytilus edulis at $0.1 \mu \mathrm{g} \mathrm{mL}^{-1}$.
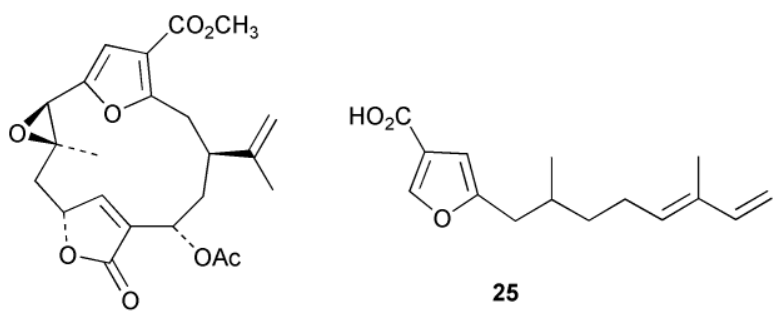

24

\section{Sinularia sp. C}

This unidentified specimen of Sinularia sp. was collected in 1991 during a cruise of the R/V Sogen Maru.
Chemistry/bioactivity: this Sinularia $\mathrm{sp}$. contained five related steroidal triols (e.g. 26) 24-methylenecholesta-3 $\beta, 5 \alpha, 6 \beta$ triol, which inhibited settlement of the blue mussel Mytilus edulis at a dose of $700 \mu \mathrm{g} \mathrm{mL} \mathrm{m}^{-1}{ }^{26}$<smiles>C=C(CCC(C)[C@H]1CCC2C3C[C@H](O)[C@@]4(O)C[C@@H](O)CC[C@]4(C)C3CC[C@]21C)C(C)C</smiles>

\subsection{Cyanophycota, Cyanophyceae, Nostocales}

\section{Lyngbya majuscula}

This sample was collected from shallow water in the lagoon close to Big Goby Marine Lake in 1995 and contained 90-95\% L. majuscula with minor amounts of Phormidium sp. or Schizothrix sp. A voucher sample (95-079) is maintained at the Scripps Institute of Oceanography.

Chemistry/bioactivity: following methanolic extraction and subsequent ethyl acetate partitioning, the ethyl acetate soluble material was fractionated following activity in an HIVintegrase inhibition assay. This led to the isolation and identification of the known cyclic peptide, dolastatin 327 as an inhibitor of the integrase with an $\mathrm{IC}_{50}$ value of $5 \mathrm{mM}$. What was of significant interest was the discovery that this agent and other similar molecules, appear to bind to plastic wells and pipette tips. Thus concentrations delivered are probably not those reported. Two other peptides that appeared to have little to no activity in this assay were also isolated and purified, homodolastatin 328 and kororamide 29. In addition to these peptides, the known cytotoxic metabolites, aplysiatoxin 30, debromoaplysiatoxin $\mathbf{3 1}$ and oscillotoxin 32 were also isolated and purified. ${ }^{27}$

\section{Lyngbya sp. (I)}

This sample was collected in 1999 at the Short Drop Off in Palau and a voucher was stored at the University of Guam (\# NIH 309).

Chemistry/bioactivity: the lipophilic extract of this material was cytotoxic to KB and LoVo cell lines and following conventional isolation techniques, two very cytotoxic peptides were purified. One was apratoxin A $\mathbf{3 3}$ previously reported from a Lyngbya sp. collected in Apra Harbor, Guam and the other, apratoxin $\mathrm{C} 34$ was novel. In both cases, their activities $\left(\mathrm{IC}_{50}\right.$ values) against $\mathrm{KB}$ and LoVo were at the sub-nanomolar level. ${ }^{28}$

\section{Lyngbya sp. (II)}

This sample was a combination of smaller collections made at various dive sites (1999-2000) in Palau and then a major collection was made in 2000 in Ulong Channel. These samples together with the one referred to above (NIH 309) were the source for the chemistry described below. Vouchers are stored for all at the University of Guam marine station.

Chemistry/bioactivity: six closely related cyclic peptides, ulongamides A-F 35-40 were isolated from these samples of Lyngbya. Unlike the apratoxins with which they share the same host, and which have cytotoxic activity at the sub-nanomolar level, five of the six compounds (A-E) are cytotoxic $\left(\mathrm{IC}_{50}\right.$ values) to $\mathrm{KB} / \mathrm{LoVo}$ at $1-5 \mu \mathrm{M}$, whereas the sixth, (F), the only one without an aromatic side-chain, is not active below $10 \mu \mathrm{M}^{29}$ 
<smiles>[R]CC[C@H](C)NC(=O)[C@H](CC(C)C)NC(=O)[C@@H](NC(=O)c1csc(CNC(=O)c2csc(C(CCC(N)=O)NC(=O)[C@@H](CC(C)C)NC(=O)C3CCCN3C)n2)n1)C(C)C[R]</smiles>

27; $\mathrm{R}=\mathrm{H}$ $28 ; \mathrm{R}=\mathrm{CH}_{3}$

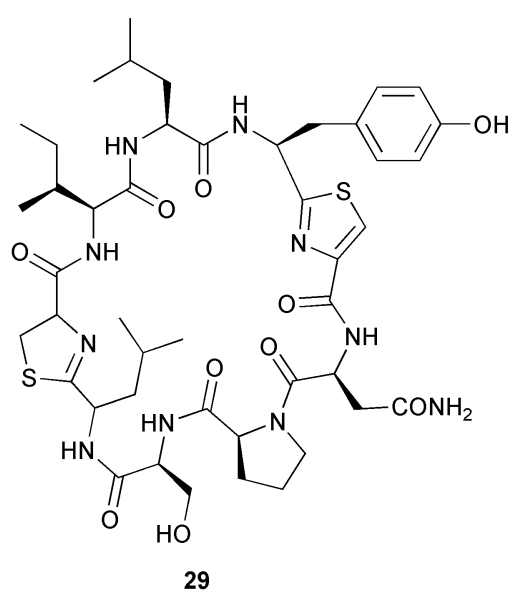

29

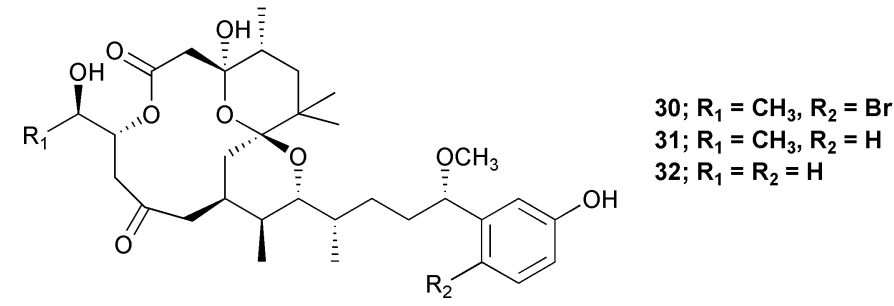

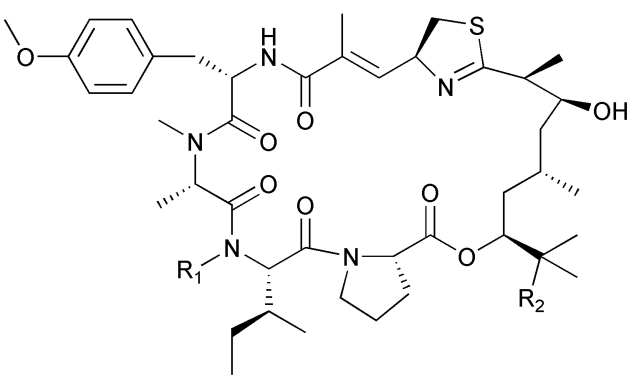

33; $\mathbf{R}_{1}=\mathbf{R}_{\mathbf{2}}=\mathrm{CH}_{3}$

34; $\mathrm{R}_{1}=\mathrm{H}, \mathrm{R}_{2}=\mathrm{CH}_{3}$

\section{Lyngbya sp. (III)}

This sample of Lyngbya was the large collection from the Ulong Channel referred to above and a voucher sample was deposited at the University of Hawaii.
Chemistry/bioactivity: in addition to the apratoxins, ulongamides and lyngbyapeptins, this collection also yielded an unusual brominated glycosidic macrolide that was named lyngbyaloside B $\mathbf{4 1}$ due to its close similarity to the previously reported lyngbyaloside $\mathbf{4 2}$. It is also a structural analogue of the recently reported lyngbouilloside $\mathbf{4 3}$ that was isolated by Gerwick's group from the cyanophyte, L. bouillonii and on reexamination of the voucher specimen, this producing organism matches the description for $L$. bouillonii. Lyngbyaloside was weakly cytotoxic against $\mathrm{KB}\left(\mathrm{IC}_{50}\right.$ of $\left.4.3 \mu \mathrm{M}\right)$ and roughly four-fold less active versus LoVo. ${ }^{30}$

\section{Lyngbya sp. (IV)}

Further investigations of the same collections as in I to III above demonstrated, yet again, the immense biosynthetic potential of these cyanophytes.

Chemistry/bioactivity: all isolations were followed using cytotoxicity against either $\mathrm{KB}$ or LoVo cells as the initial

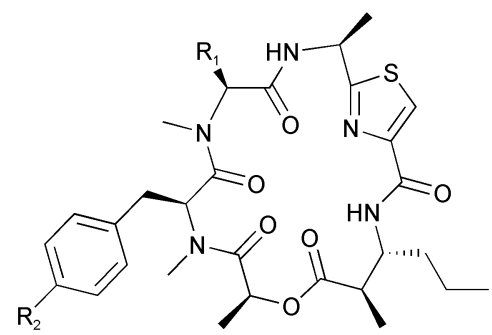

35; $\mathrm{R}_{1}=i-\mathrm{Pr} ; \mathrm{R}_{2}=\mathrm{H}$

$36 ; R_{1}=i-P r ; R_{2}=O H$ $37 ; R_{1}=\mathrm{Bn} ; \mathrm{R}_{2}=\mathrm{OH}$<smiles>[R]C[C@H](C)[C@H](OC(=O)[C@H](C)[C@H](CCC)NC(=O)c1csc(C(C)NC(=O)[C@@H](C(C)C)N(C)C(=O)[C@H](Cc2ccc(O)cc2)N(C)C)n1)C(C)C</smiles>

38; $\mathrm{R}=\mathbf{H}$

39; $\mathrm{R}=\mathrm{CH}_{3}$<smiles>CCC[C@H](NC(=O)c1csc(C(C)NC(=O)C(C(C)C)N(C)C(=O)C(C(C)C)N(C)C(=O)C(OC(=O)[C@H](C)C(C)CC)[C@@H](C)CC)n1)C(C)C</smiles> 


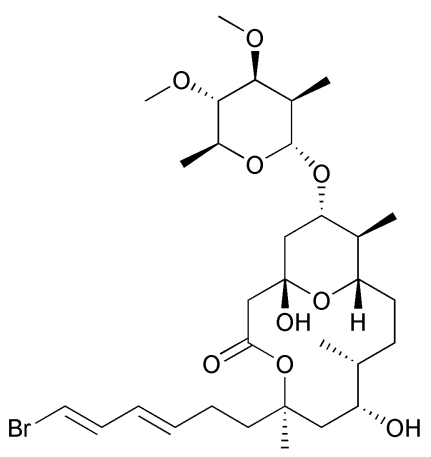

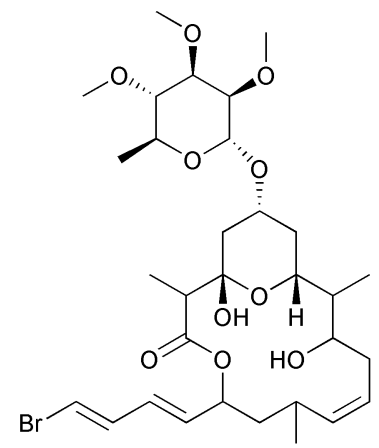

41<smiles>CO[C@H]1[C@H](O)[C@@H](OC)C(=O)O[C@@H]1C</smiles>

42

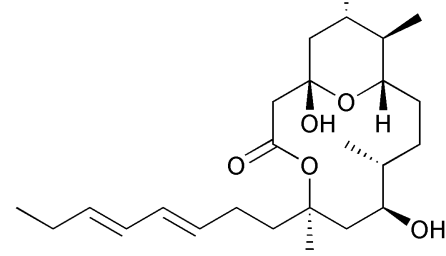

43<smiles>CC[C@H](C)[C@H](NC(=O)CNC(=O)c1csc(C(OC(=O)C(C)(C)C(CCCC(C)(Cl)Cl)OC(=O)c2csc(C(C)(C)O)n2)C(C)(C)O)n1)C(C)(C)O</smiles>

44<smiles>CCC(C)(O)C(OC(=O)C(C)C(CCCC(C)(Cl)Cl)OC(=O)c1csc(C(O)CO)n1)c1nc(C(=O)OC)cs1</smiles>

46<smiles>CCC(C)(O)C(OC(=O)C(C)C(CCCC(C)(Cl)Cl)OC(=O)c1csc(C(O)COC(=O)c2csc(C)n2)n1)C(C)(C)C</smiles>

45<smiles>COC(=O)c1csc([C@@H](O)CO)n1</smiles>

47 indicator. Whilst investigating the apratoxin producers from Guam, lyngbyabellin A $\mathbf{4 4}$ was found. ${ }^{31}$ This compound, together with a weaker $\left(\mathrm{IC}_{50}\right.$ values of $\left.2-5 \mu \mathrm{M}\right)$ cytotoxic analogue, named lyngbyabellin C $\mathbf{4 5}$ were isolated from the Short Drop Off collection. What is of interest is that during the isolation of the latter compound, a methanolysis of one of the ring ester groups occurred, giving rise to a linear compound that was named as homohydroxydollabellin $\mathbf{4 6}$ because of its resemblance to the $D$. auricularia metabolite, dollabellin 47 reported by Yamada's group in $1995 .^{32}$ Since in the Palauan case, the linear compound had effectively the same cytotoxicity as the cyclic precursor, and methanol was used extensively in the isolation of dollabellin, it is probable that this compound is an artifact of the isolation protocol and thus demonstrates that the actual source should be searched for once the material has been isolated from its host.

From the "mixed collection" another quite cytotoxic material ( $\mathrm{IC}_{50}$ 's in the 0.4 to $1 \mu \mathrm{M}$ range) was obtained. It was not encountered in any of the Guamanian collections and in only the one Palauan sample. This was the mixed amide-imide compound that was given the trivial name of palau'imide $48 .{ }^{31}$<smiles>CCCCC(C)C(=O)NC(C(=O)N1C(=O)C(C)=C(OC)[C@H]1Cc1ccccc1)C(C)C</smiles>

Finally, from the work-up of all of these compounds, two non-cytotoxic tetrapeptides related to the known lyngbyapeptin A 49, lyngbyapeptins B 50 and C 51 were isolated and purified from side-cuts. These latter two were not reported from any of the apratoxin-containing Guamanian samples, nor was the former compound found in the Palauan samples. ${ }^{31}$ 
<smiles>CC[C@H](C)[C@H](C(=O)N1CCC[C@H]1c1nccs1)N(C)C(=O)[C@H](CC(C)C)N(C)C(=O)[C@H](Cc1ccc(OC)cc1)N(C)C(=O)C=C(C)OC</smiles><smiles>[R]/C(=C\C(=O)N(C)[C@H](Cc1ccc(OC)cc1)C(=O)N(C)[C@H](C(=O)N(C)[C@H](Cc1ccc(OC)cc1)C(=O)N[C@@H](C)c1nccs1)C(C)C)OC</smiles>

50; $\mathrm{R}=\mathrm{CH}_{3}$ 51; $\mathrm{R}=\mathrm{CH}_{2} \mathrm{CH}_{3}$

Symploca sp. (I)

This sample of Symploca was collected in 1999 at Short Drop Off in Palau and a voucher was deposited at the University of Guam (\#NIH 304).

Chemistry/bioactivity: the lipophilic extract of this material demonstrated potent solid tumour selectivity and following bioactivity-driven isolation, the linear peptide tasiamide $\mathbf{5 2}$ (now tasiamide A) was isolated and purified demonstrating cytotoxicity against both $\mathrm{KB}$ and LoVo cells in the $\mu \mathrm{g} \mathrm{mL}^{-1}$ range. ${ }^{33}$ This linear peptide's closest match in cyanobacterial metabolites is malevamide A which shares approximately half of the sequence. Very recently, further workup of the aqueous extract of this same collection by following bioactivity against the KB cell line yielded the linear peptide tasiamide B 53 containing the unusual amino acid, 4-amino-3-hydroxy5-phenylpentanoic acid, that had previously been reported as a component of protease inhibitors from Candida and Streptomyces spp. ${ }^{34}$

\section{Symploca sp. (II)}

A second collection from the same general area (Short Drop Off) was made in 2000 and a larger sample was obtained with the voucher sample being deposited at the Smithsonian Marine Station in Fort Pierce, FL (\# NIH 304).

Chemistry/bioactivity: in contrast to tasiamide, the two

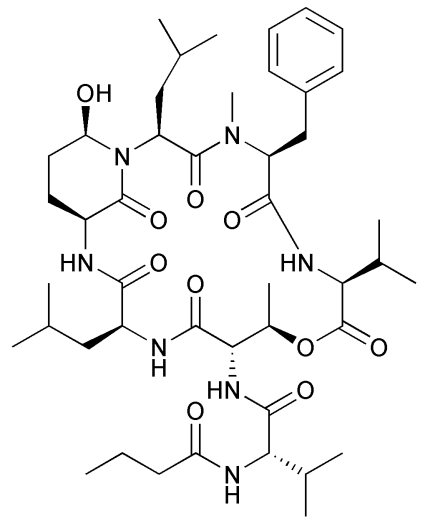

54<smiles>CCCC(=O)N[C@@H](C(=O)NC(CC(C)C)C(=O)NC1CC[C@@H](O)N([C@H](CC(C)C)C(=O)N(C)C(Cc2ccccc2)C(=O)NC(C(=O)NC(Cc2ccccc2)C(C)C)C(=O)OC(C)C(C)C)C1=O)C(C)C</smiles>

55 cytotoxic peptides that were purified from this preparation were in the hydrophilic fraction. These two closely related cyclic peptides were named tasipeptin A $\mathbf{5 4}$ and tasipeptin B $\mathbf{5 5}$ and demonstrated activity against $\mathrm{KB}$ cells with $\mathrm{IC}_{50}$ concentrations at the $1 \mu \mathrm{M}$ level. ${ }^{35}$

\subsection{Miscellaneous bacteria/fungi}

\section{Pelagiobacter variabilis}

This marine bacterium was isolated from the macro-alga Pocockiella variegata collected in Palau and then cultured in Difco marine broth rather than in one of the more esoteric culture media.

Chemistry/bioactivity: the culture filtrate contained the known compound griseoluteic acid and three new phenazine derivatives, pelagiomicins A 56-C. Of these, pelagiomicin A was reported to exhibit antimicrobial and antitumour activity. ${ }^{36}$<smiles>COc1ccc(COC(=O)C(N)C(C)(C)C)c2nc3cccc(C(=O)O)c3nc12</smiles>

\section{Pseudoalteromonas sp. F-420}

This marine bacterium was isolated from the green alga Halimeda sp. collected in shallow water off Koror.<smiles>CCC(C)[C@H](NC(=O)[C@@H](CCC(N)=O)N(C)C(=O)[C@H](CC(C)C)NC(=O)[C@@H](O)[C@@H](C)CC)C(=O)NCC(=O)N(C)[C@H](Cc1ccccc1)C(=O)N1CCC[C@H]1C(=O)OC</smiles>

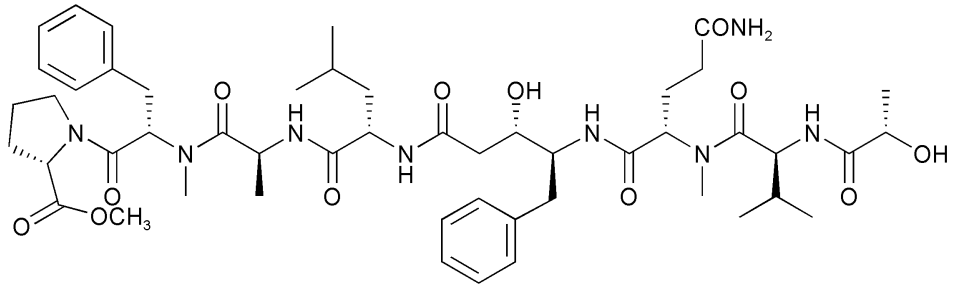


Chemistry/bioactivity: following isolation and subsequent fermentation in Difco marine broth, this bacterium, Pseudoalteromonas sp. F-420, produced a new lipid metabolite, korormicin 57 that was active against marine (halophilic) Gram-negative bacteria, but was not active against marine (halophilic) Gram-positive bacteria and terrestrial microorganisms irrespective of Gram type. ${ }^{37}$ This molecule might serve as a method of defining such Gram-negative marine microbes.<smiles>CCCCCCC1OC1C/C=C/C=C\C(O)NC(=O)CC1=CC(C)(CC)OC1=O</smiles>

\section{Myrothecium roridum}

This filamentous fungus was isolated from a small sample of woody material collected from the bottom of a coral reef at a depth of $5 \mathrm{~m}$ in 1998 during a cruise by the training vessel T/V Umitaka-maru.

Chemistry/bioactivity: the fungus was cultivated in halfstrength potato-dextrose medium in seawater and the materials isolated from an acetone/ethyl acetate treatment/extraction following their bioactivity against HL-60 and L1210 tumour lines. One new trichothecene, 12,13-deoxyroridin E 58 and three previously described trichothecenes, roridin E 59, verrucarin A 60 and verrucarin $\mathbf{J} \mathbf{6 1}$ were also isolated. The novel derivative of roridin $\mathrm{E}$ was about 80 fold less active than the parent epoxycontaining roridin $\mathrm{E}^{38}$

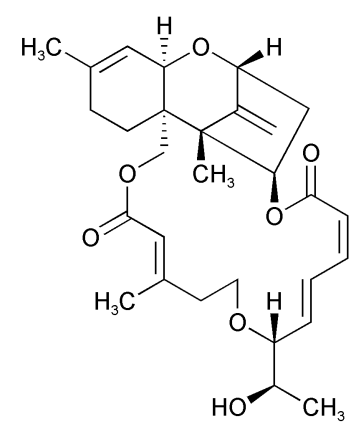

58

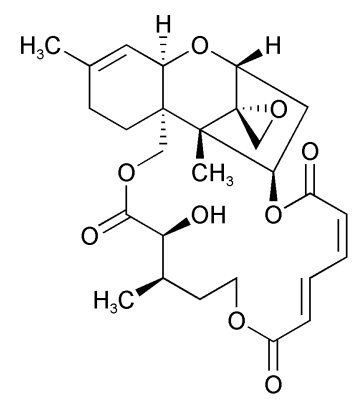

60

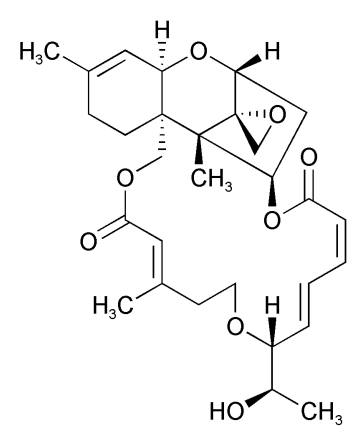

59

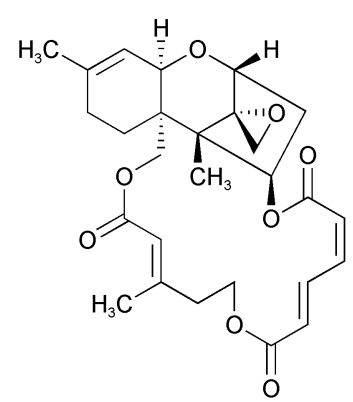

61

\section{Microbial Phylogenies}

The invertebrates and waters around Palau are laden with as yet undescribed microbes. As an example, in 2001, Suzuki et al. from the Kyowa Hakko Kogyo company published an article that utilized sequence information from five microbes isolated from Palauan sponges and algae that permitted the identification of a completely new taxon of bacteria, the genus Tenacibaculum. ${ }^{39}$

\subsection{Mollusca}

\section{Lamellaria sp}

This Lamellaria sp. is a black-colored prosobranch mollusc that feeds on ascidians and may well be nocturnal. Six specimens were collected during a night dive at Peduliaes Headland at the entrance to Malakal Harbor and a few others have been sighted in relatively shallow water.

Chemistry/bioactivity: lamellarins A 62-D were isolated from specimens of Lamellaria sp. and the structure of $\mathbf{6 2}$ was determined by X-ray crystallography. ${ }^{40}$ Subsequently, the same compounds were isolated from the ascidian upon which the mollusc was feeding. These compounds inhibited the cell division of fertilized sea urchin eggs.<smiles></smiles>

62

\subsection{Mollusca, Gastropoda, Nudibranchia}

\section{Chromodoris funerea}

This black and white striped dorid nudibranch was collected in the shallow waters of Iwayama Bay near the Nikko Hotel and also from the Kaibakku Marine Lake.

Chemistry/chemical ecology: the specimens from the marine lake contained 12-epi-scalarin 63, deoxoscalarin 64, luffariellins C 65 and D 66, and 3-ketodeoxoscalarin 67, which are all considered to be metabolites of dictyoceratid sponges. In contrast, the specimens from Iwayama Bay contained furodysin 68 , furodysinin 69, and their singlet oxygen oxidation products, and the pentabrominated biphenyl ether 70, all of which have been found in species of Dysidea from the same location. ${ }^{41,42}$ Dorid nudibranchs are known to sequester allelochemicals from their sponge diets and use them for their own defense.

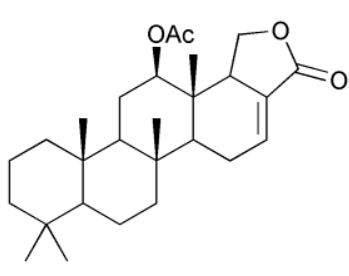

63

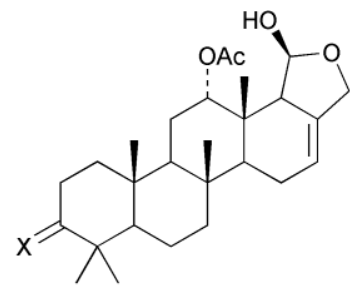

$64 ; X=H_{2}$
From this study one may conclude that the ability of C. funerea, and dorid nudibranchs in general, to distinguish allelochemicals from other metabolites is not dependent on the nudibranch being adapted to a specific food source.

\subsection{Porifera}

\section{Unidentified sponge or mixture of sponges}

The sponge, or sponges, were collected by the Suntory Institute for Biomedical Research prior to 1986, but cannot be identified as though the paper mentions Halichondria sp. and Dictyoceratida sp., since the latter is the name of an order of sponges, any identification is suspect.

Chemistry/bioactivity: the specimen(s) contained six scalarin-type sesterterpenes (e.g. 71) ${ }^{43}$ three of which had been 
<smiles>C=C(C)[C@@]1(CC/C(C)=C/CC/C(C)=C/CCC2=CC(=O)OC2)CCC[C@@H]1C</smiles>

65

66<smiles>CC1=C[C@H]2Cc3occc3C(C)(C)[C@H]2CC1</smiles>

68<smiles>CC1CC[C@@H]2[C@@H](Cc3ccoc3C2(C)C)C1</smiles>

69<smiles>Oc1cc(Br)c(Br)c(Br)c1Oc1ccc(Br)cc1Br</smiles>

70 described previously from an Australian Lendenfeldia sp. $^{44}$ and it was reported that 24-methylscalaradial $\mathbf{7 1}$ inhibited platelet aggregation with an $\mathrm{IC}_{50}$ of $0.5 \mu \mathrm{g} \mathrm{mL} \mathrm{m}^{-1}$.<smiles>CC(=O)C1=CCC2[C@](C)(C(OC=O)C[C@@H]3C4(C)CCCC(C)(C)C4CC[C@@]23C)[C@H]1C=O</smiles>

7.8 Porifera, Demospongiae, Agelascida

\section{Agelas sp}

A massive orange sponge that is fairly common on the reefs of Palau (the specimen studied was from Argulpelu Reef). Van Soest ${ }^{45}$ considered this specimen to be A. mauritiana and also considered the Japanese sponge $A$. nakamurai to be the same as A. mauritiana. Chemical studies certainly support these proposals.

Chemistry/bioactivity: the Agelas sp. contained agelines A 72 and B 73, and agelasidine A $\mathbf{7 4}$ in good yields but they were difficult to separate. ${ }^{46}$ Agelines A and B are quaternary 9-methyladenine salts of diterpenes that are unstable in basic conditions whereas agelasidine $\mathrm{A}$ is a taurocyamine derivative of a sesquiterpene. Compounds $\mathbf{7 2}$ and $\mathbf{7 3}$ were also reported from A. nakamurai. Compounds $\mathbf{7 2}$ and $\mathbf{7 3}$ were antimicrobial and ichthyotoxic, and although the crude extract of the sponge was cytotoxic, neither of these compounds was active. Related compounds from $A$. mauritiana and $A$. nakamurai were reported to be cytotoxic and to inhibit the enzymatic activity of $\mathrm{Na} / \mathrm{K}$ ATPase. There are no known uses and the instability of agelines A and B and related salts makes them unlikely candidates for commercial development.

\subsection{Porifera, Demospongiae, Astrophorida}

\section{Asteropus sarasinosum}

This massive sponge is found growing out of sandy substrates. Although collected in Koror Harbor, it is probably the same sponge as the Asteropus sp. collected in Guam and Chuuk.

Chemistry/bioactivity: a total of nine closely related saponins called sarasinosides $A_{1}, 75, A_{2}, A_{3}, B_{1}, B_{2}, B_{3}, C_{1}, C_{2}$, and $C_{3}$ were isolated. ${ }^{47,48}$ These saponins consist of 4 or 5 sugar units, two of which are amino-sugars, linked to a 14-nor-lanostane triterpenoid and are somewhat similar in structure to the saponins found in sea cucumbers. Like all saponins, the sarasinosides are ichthyotoxic (the saponins are thought to cause hemolysis of gill tissues) and are cytotoxic due to their action on cell membranes, where they cause irreversible non-specific lysis.

\section{Jaspis sp. (aka Dorypleres splendens)}

This orange sponge was collected in a marine lake in Palau and in Fiji. It appears to be fairly common throughout Palau. In other parts of the Pacific, this sponge has been collected under a variety of names, including Jaspis splendens. The identification as Dorypleres splendens was made by Dr Michelle Kelly(-Borges) working with the materials collected for a largescale jaspamide isolation project involving the NCI collection contractor, the Coral Reef Research Foundation in Palau and Yap.

Chemistry/bioactivity: this Jaspis sp. contains jaspamide $\mathbf{7 6}$ as the major metabolite ${ }^{49}$ which is also known as jasplakinolide when isolated from a Fijian-derived sample of Jaspis johnstoni. ${ }^{50}$ Modified jaspamides have been reported from the sponge Jaspis splendens collected in Vanuatu. ${ }^{51}$ Jaspamide was initially reported to be a potent insecticide and antifungal agent ${ }^{49,50}$ but subsequent work by NCI scientists demonstrated<smiles></smiles>

72<smiles>C[C@H]1CC[C@]2(C)[C@@H](COC(=O)c3ccc[nH]3)CCC[C@H]2[C@@](C)(CCCn2c[n+](C)c3ncnc(N)c32)C1Cl</smiles>

73<smiles>C=CC(C)(CC/C=C(\C)CCC=C(C)C)CCC(=O)NCC(=N)N</smiles>

74 


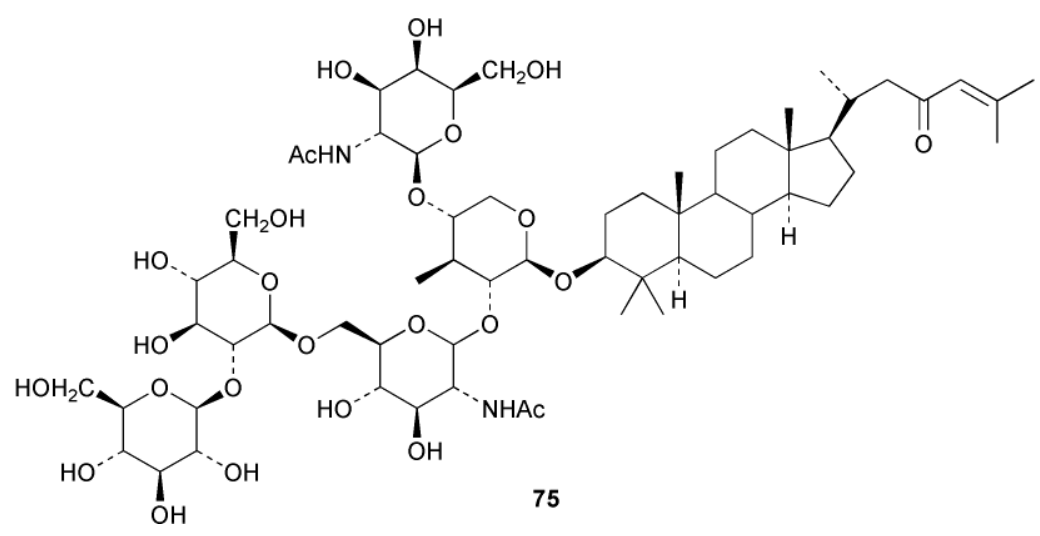

that it induces actin polymerization in vitro leading to disruption of the actin skeleton. ${ }^{52,53}$ However, in spite of many attempts at NCI, no reproducible in vivo antitumour activity could be demonstrated due to the therapeutic index being very close to unity. In this respect, it is similar to the effects seen with other actin inhibitors such as the latrunculins and cytochalasins.<smiles>CC(=CC(C)CC(C)OC(=O)CC(NC(=O)C(Cc1c(Br)[nH]c2ccccc12)N(C)C(=O)C(C)NC(=O)C(C)C)c1ccc(O)cc1)CC(C)C</smiles>

76

The question as to the actual source of these molecules is open to debate as very similar molecules, the geodiamolides, were first reported ${ }^{54}$ from a Geodia sp. in 1987 and from other taxonomically distant sponges in following years, ${ }^{55}$ Similar molecules, the chondramides, with an 18 membered macrolide ring, were reported from a terrestrial myxobacteria, by the Reichenbach group in $1995,{ }^{56}$ with actin stabilizing activity of these compounds being reported in $1998 .{ }^{57}$

Thus, is the sponge the actual source of the jaspamides or merely a host (commensal or co-metabolic) to microbes that produce these peptides?

\subsection{Porifera, Demospongiae, Axinellida}

\section{Axinella sp}

This sponge is described as having a brownish-yellow exterior of irregular mass and it must be fairly abundant as over $200 \mathrm{~kg}$ of sponge was collected by Pettit's group, an amount normally considered excessive by most investigators.

Chemistry/bioactivity: the first metabolites to be reported from this sponge were hymenialdesine, debromohymenialdesine (see Stylotella aurantium) and axinohydantoin 77, which possibly resulted from hydrolysis of hymenialdesine. ${ }^{58}$ Bioassayguided fractionation using a leukemia cell line resulted in the isolation of very small quantities of halichondrin B $\mathbf{7 8}$ and

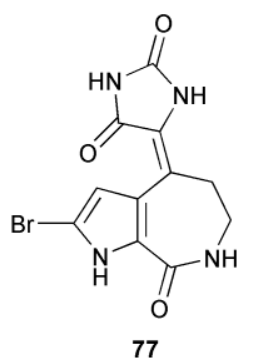

homohalichondrin B, which had previously been obtained from a Japanese Halichondria sp., and three new cyclic peptides, axinastatins 1 79, 2 and $3 .^{59,60}$ Although discovered using an anti-leukemia assay, the axinastatins were cytotoxic against several tumour cell lines including representative ovarian, CNS, renal, lung, colon and melanoma lines. Following the syntheses a few years later, ${ }^{61,62}$ the original report of the bioactivity of the axinastatins was questioned when it was found that the synthetic compounds had only a fraction of cytotoxicity claimed for the natural products, but the reason for the discrepancy is not known. Finally, a synthetic derivative of halichondrin B is currently in Phase I clinical trials for cancer.

\section{Raspailia (Raspaxilla) sp}

Raspailia (Raspaxilla) sp. is a small orange sweet-smelling sponge that was collected from the outer side of the reef west of Koror with a voucher specimen deposited in the SIO Benthic Invertebrate Collection (\# P-1151).

Chemistry/bioactivity: the sponge contained two homologous cyclic hemiketals $\mathbf{8 0}$ and $\mathbf{8 1}$ but without any reported bioactivity. ${ }^{63}$

\subsection{Porifera, Demospongiae, Dendroceratida Chelonaplysilla sp}

This small deep purple dendritic sponge was collected from a marine lake on Kaibaku Island in 1981 and 1990. Though originally considered to be a Dendrilla sp., it was subsequently identified in 1990 as a Chelonaplysilla $\mathrm{sp.}$

Chemistry/bioactivity: after reidentification of the sponge, four alkaloids, chelonin A 82, chelonin B 83, bromochelonin B $\mathbf{8 4}$ and chelonin C 85 were reported as metabolites of Chelonaplysilla sp. ${ }^{64}$ Compounds 82-84 exhibited antimicrobial activity against Bacillus subtilis and in addition, chelonin A 82 demonstrated in vivo antiinflammmatory activity.

\section{Dendrilla sp}

This small, deep purple dendritic sponge of the genus Dendrilla was collected from a marine lake on Kaibakku Island in Iwayama Bay in both 1981 and 1988. Subsequently, this particular sponge was reclassified as a Chelonaplysilla sp. ( $c f$ above).

Chemistry/bioactivity: the 1981 collection contained dehydroambliol A 86, previously described from Dysidea amblia, ${ }^{65}$ norrisolide 87, a known metabolite of the spongivorous dorid nudibranch Chromodoris norrisi ${ }^{66}$ and four new compounds, 1-bromo-8-ketoambliol A acetate 88 and dendrillolides A 89 B, and C 90. ${ }^{67}$ The 1988 collection yielded four additional compounds, dendrillolides D 91 and E 92, 12-desacetoxypolyraphin A 93 and 12-desacetoxyshahamin C 94, together with a reassessment of the structure of dendrillolides $\mathrm{A}$ and $\mathrm{B}$, where dendrillolide A should have the original structure assigned to dendrillolide B with the structure of dendrillolide B being currently unknown. ${ }^{68,69}$ No bioactivity was recorded 


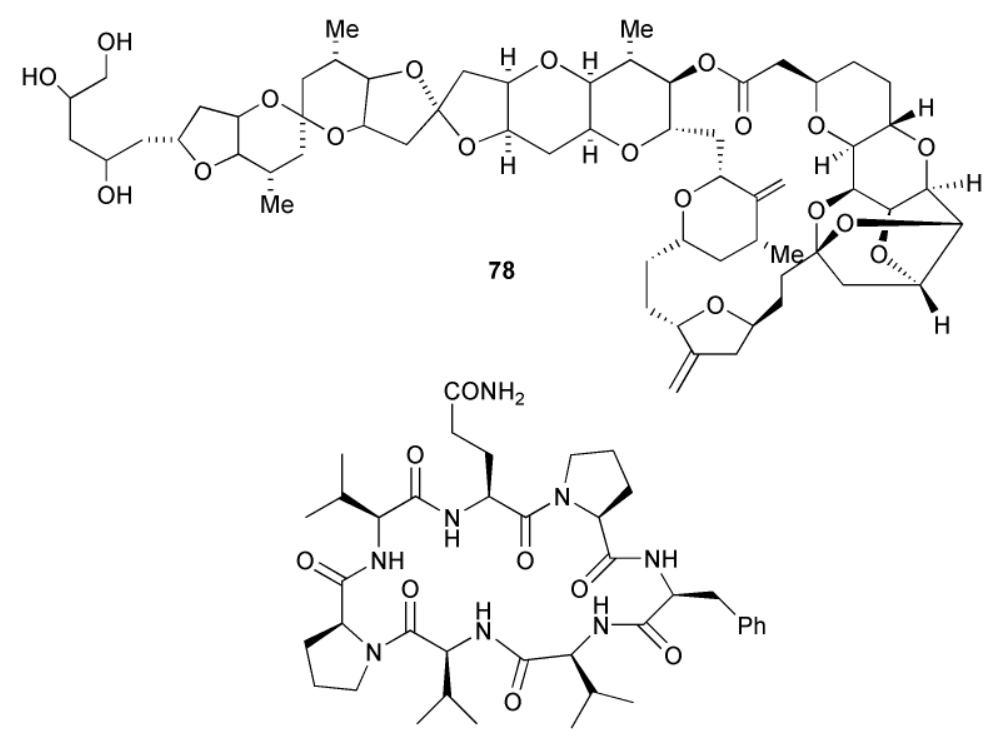

79<smiles>[R]CCCC=CC=CC(C)CC(C)=CC=CCCCC=C</smiles>

82<smiles>[R]c1ccc2[nH]cc(CCNCC(O)c3ccc(OC)c(Br)c3)c2c1</smiles>

83; $\mathrm{R}=\mathrm{H}$

$84 ; \mathrm{R}=\mathrm{Br}$<smiles>COc1ccc(C2CNCC(c3ccc(O)cc3)O2)cc1OC</smiles>

85

originally but recently Blackburn found that dendrillolide A 89 causes vesiculation of Golgi membranes (C. Blackburn, pers. comm.).

\section{Igernella sp}

The sample of Igernella sp. was collected from the fringing reef on the Southeastern side of Palau.

Chemistry/bioactivity: this sample contained the known compound halisulfate $3 \mathbf{9 5}$, which exhibited modest antimicrobial activity and had previously been reported from a Californian halichondrid sponge,$^{70}$ together with the new sesterterpene igemellin $96 .{ }^{71}$

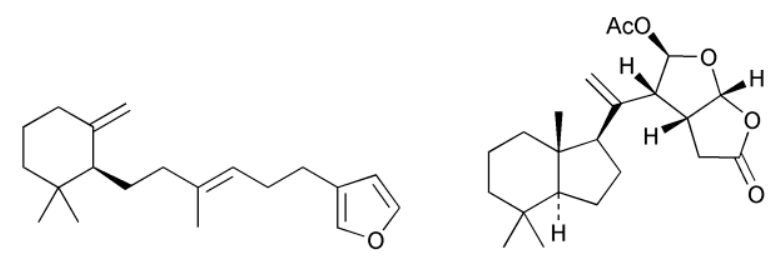

86

87

88

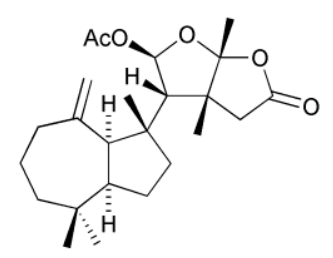

89<smiles>CC(=O)C[C@@H]1C(=O)O[C@@H]2[C@@]3(C)CCCC(C)[C@@H]3CC[C@]2(C)[C@@H]1CC(=O)OC(C)=O</smiles>

91

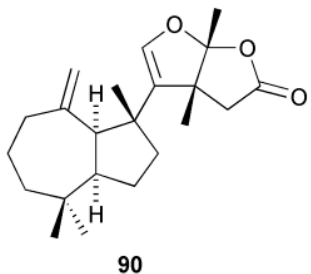

90

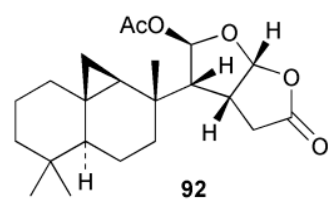

92

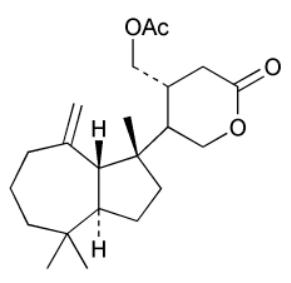

94

7.12 Porifera, Demospongiae, Dictyoceratida

\section{Coscinoderma sp}

The Coscinoderma sp. (originally called Ircinia sp.) was found in both Fiji and Palau. 
<smiles>CC1=CCCC(C)(C)C1CC/C(C)=C/CCC(CO)CCCc1ccoc1</smiles>

95

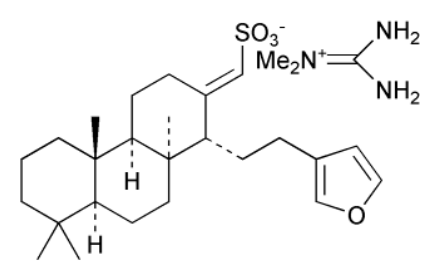

97

Chemistry/bioactivity: the major metabolite in Coscinoderma sp. was suvanine 97, the structure of which was corrected as a result of studies of the Palauan specimen. ${ }^{72}$ Suvanine 97 facilitates neuromuscular transmission in indirectly stimulated rat hemidiaphram preparations (Jacobs, unpublished data), is an acetylcholinesterase inhibitor and Kimura et al. ${ }^{73}$ reported that they had isolated it by following serine protease inhibitory activity from a sample of Coscinoderma mathewsi collected in Pohnpei. They found that the activity against trypsin and thrombin was independent of the counter-ion, thus the known activity of the guanidine moiety was not the responsible factor.

\section{Dactylospongia sp}

A small specimen of this sponge of the genus Dactylospongia was collected at a depth of 15 metres at Bairakaseru Reef in 1985.

Chemistry/bioactivity: the sponge contained ilimaquinone 98 (cf. Hippospongia metachromia), dictoceratidin A 99. which had previously been isolated from a Hippospongia sp. $^{74}$ and five new compounds, dactylospongenones A-D 100-103 and dictoceratidin $\mathrm{C} \mathrm{104} .{ }^{75}$ No bioactivity was recorded for the new compounds although the crude extract of the sponge was antimicrobial, probably due to the presence of ilimaquinone.

\section{Dysidea sp. (general comments)}

Sponges of the genus Dysidea are very common in Palau, where they are often found in shallow water in lagoons and near
96<smiles>C=C1CCC[C@@H]2C1C1=C(O)[C@@](C)(CC[C@@H](C)[C@H]2C)C(=O)C(OC)=CC1=O</smiles>

98<smiles>C=C1CCC[C@H]2[C@@H](Cc3cc(C(=O)OC)cc(O)c3O)[C@H](C)CC[C@]12C</smiles>

99 the tops of the reefs. At least three different Dysidea species can usually be seen near the landing dock at the Hotel Nikko. The taxonomy of the Dysidea species in Palau is somewhat confused because the same species may take on different growth forms in response to environmental factors. Chemotaxonomy is unlikely to be helpful because the chemical compounds may well be produced by symbiotic cyanobacteria or by a "co-metabolic process" between the cyanophyte and the host organism

\section{Dysidea chlorea}

This sponge was collected near the Hotel Nikko Dock and was separated with difficulty from other Dysidea species.

Chemistry/bioactivity: D. chlorea contained only 2-(2',4'dibromophenoxy)-4,6-dibromophenol 105 which demonstrated strong antimicrobial activity. ${ }^{76}$

\section{Dysidea herbacea}

This is probably the most common species of Dysidea in the shallow waters of Palau and it can always be found across from the dock of the Hotel Nikko. Collections were also made from Kaibaku marine lake and from the reef-top at Ngemelis dropoff, where it overgrows a red coralline algae (Jania sp.). The sponge contains symbiotic cyanobacteria (Oscillatoria spongeliae) to the extent of about $50 \%$ of the mass - this is very

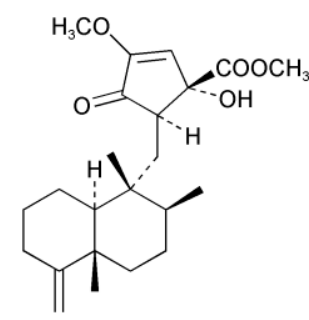

100<smiles>C=C1CCC[C@H]2[C@@H](C[C@H]3C(=O)C(OC)=C[C@]3(O)C(=O)O)[C@H](C)CC[C@]12C</smiles>

101<smiles>C=C1CCCC2C1CCC(C)C2CC1C(=O)C(OC)=CC1C(=O)OC</smiles>

102<smiles>C=C1CCC[C@H]2[C@@H](C[C@H]3[C@@H](C)CC[C@]4(C)C(=O)C(OC)=C[C@]34O)[C@H](C)CC12C(C)=O</smiles>

103<smiles>C=C1CCC[C@@H]2C(C)[C@@]1(C)CC[C@@H](Cc1cc(C(=O)OC)ccc1O)[C@@H]2C</smiles>

104 
unusual among sponges other than Dysidea spp. D. herbacea from Palau is illustration \#204 in Colin and Arneson. ${ }^{77}$

Chemistry/bioactivity: in 1972, one of the first studies of marine sponges from a secondary metabolite aspect was performed on Dysidea herbacea from Palau. In this study, Sharma and $\mathrm{Vig}^{78}$ reported the isolation of two antimicrobial agents, 2(4'-bromophenoxy)-3-bromophenol 106 and 2-(2',4'-dibromophenoxy)-3,4,5-tribromophenol 107. In a later study in 1981 , Carte and Faulkner ${ }^{76}$ also reported the isolation of $\mathbf{1 0 7}$ together with 2-(2',4'-dibromophenoxy)-4,5,6-tribromophenol 108 and 2-(2',4'-dibromophenoxy)-3,5-dibromophenol 109 from the Hotel Nikko samples.<smiles>Oc1c(Br)cc(Br)cc1Oc1ccc(Br)cc1Br</smiles>

105<smiles>Oc1cccc(Br)c1Oc1ccc(Br)cc1</smiles>

106<smiles>[X]c1c([X])c(Br)c([X])c(Oc2ccc(Br)cc2Br)c1O</smiles>

107; $\mathrm{X}=\mathrm{Y}=\mathrm{Br}$ 108; $\mathrm{X}=\mathrm{H}, \mathrm{Y}=\mathrm{Z}=\mathrm{Br}$ 109; $X=B r, Y=Z=H$

In contrast, the Kaibakku Marine Lake specimen contained 10-dechloro- $N$-methyl-dysideathiazole 110, 9,10-didechloro- $N$ methyldysideathiazole 111, 10-dechloro-dysideathiazole 112, and dysideathiazole 113 and the Ngemelis specimen yielded dysideapyrrolidone and $111 .{ }^{79}$

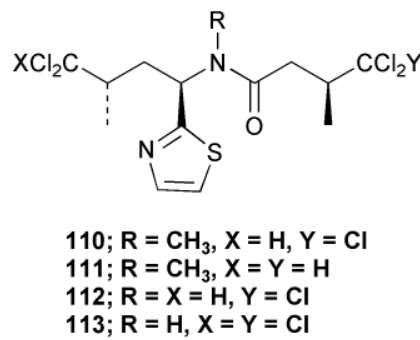

Symbiosis studies: using a specimen of $D$. herbacea from the Hotel Nikko Dock site, Unson et al. ${ }^{80}$ demonstrated that 2-(2',4'-dibromophenoxy)-4,6-dibromophenol 105 was localized in, and presumably produced by, the cyanobacterium Oscillatoria spongeliae. Crystals of $\mathbf{1 0 5}$ were also found just beneath the surface of the sponge: it is assumed that the cyanobacteria release such large quantities of $\mathbf{1 0 5}$ (which is essentially insoluble in water), that it crystallizes on exposure to seawater.

\section{Dysidea sp}

This unidentified species of Dysidea was collected in 1981 at a depth of $30 \mathrm{~m}$ along the outer reef due west of Malakal Harbor.

Chemistry/bioactivity: 15-acetylthiofurodysinin lactone $\mathbf{1 1 4}$ was isolated as a result of bioassay-driven isolation as a partial agonist using a human lung $\mathrm{LTB}_{4}$ receptor-binding assay linked to calcium mobilization. ${ }^{81}$ Although the scientists at then Smith Kline \& French, now Glaxo SmithKline, performed QSAR studies these were never published.<smiles>CC1(C)C2=CC(=O)O[C@@]2(O)C[C@H]2C=C(C[Ge])CC[C@H]2C1(C)C</smiles>

114

Another example of this genus was also collected in 1981 at a depth of $20 \mathrm{~m}$ at Short Drop Off and was subsequently stored in methanol for 15 years prior to work-up. A voucher specimen was deposited in the SIO Benthic Invertebrate Collection (\#P 1172).

Chemistry/bioactivity: three new dolabellane diterpenes $\mathbf{1 1 5}$ 117 and an unstable 14-membered macrolide, arenolide 118 were isolated from this sponge. All demonstrated modest cytotoxicity, but the isolation of these classes of compounds from this genus was previously unknown. Extensive reinspection of the sponge sample demonstrated that it was an example of a Dysidea sp. and did not appear to contain any gorgonian or brown algal contaminants/symbionts. A possible answer is that this particular sponge had adsorbed materials from its surroundings, a scenario that has been proposed to account for the presence of red algal metabolites in sponges. ${ }^{82}$

\section{Fenestraspongia sp}

This sponge was collected near Urakthapel Island but due to the condition of the voucher specimen of the sponge, it could not be further identified.

Chemistry/bioactivity: the sponge contained a $6: 4$ mixture of ilimaquinone 98 (see Dactylospongia sp.) and 5-epiilimaquinone ${ }^{83} 119$, with the latter compound inhibiting fish-feeding at $5 \mathrm{pg} \mathrm{mg}^{-1}$ of pellet.

\section{Hippospongia metachromia}

This "dirty" yellow sponge is found commonly on the reefs around Palau and throughout the Indo-Pacific with a repre-

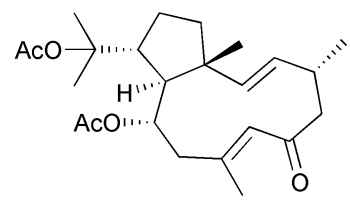

115<smiles>COC(C)(C)C1CCC(C)(C=CC(C)=CC(=O)CC(C)C)C1C(C)(C)C</smiles>

116<smiles></smiles>

117<smiles>C=C(CCCC(O)CC(C)O)C[C@H](CC(=C)C[C@@H](O)C/C(C)=C/[C@H](O)CCCC(=O)O)OC(=O)CCC(C)O</smiles>

118 
<smiles></smiles>

119

sentative photograph of the sponge in Colin and Arneson ${ }^{77}$ (entry 192).

Chemistry/bioactivity: the merosesquiterpene ilimaquinone 98 was first isolated from a specimen of $H$. metachromia from Hawaii ${ }^{84}$ whereas the bioactivity studies referred to below used ilimaquinone isolated from Palauan specimens of $H$. metachromia and Dactylospongia elegans. Ilimaquinone is generally regarded as a nuisance compound because it is active in too many bioassays. It has been patented for use against cancer and HIV but it is unlikely to be used in treating humans because of its non-specific activity. However, as a result of demonstrating that ilimaquinone causes reversible breakdown of the Golgi membranes and disruption of the microtubule network in normal rat kidney cells, ${ }^{85}$ it is now being used as a biochemical probe to study the dynamics of Golgi membranes and their role in sorting, modifying and distributing proteins.

\section{Luffariella sp}

Studies on two specimens of Luffariella sp. from Palau have been reported. The first specimen (from 1985) was collected at Short Drop Off. The second specimen (from 1995) was collected in shallow water at "Tee" marine lake. In both cases, the specimens had a fine tertiary fibre network that is typical of the genus Luffariella.

Chemistry/bioactivity: the first specimen (from 1985) contained luffariellolide $\mathbf{1 2 0}$ as a major constituent comprising $14.5 \%$ by dry weight ${ }^{86}$ and luffolide $\mathbf{1 2 1}$ as a minor metabolite. ${ }^{87}$ In contrast, the second specimen (from 1995) contained three 9,11-secosterols, luffasterols A $\mathbf{1 2 2}-\mathrm{C}$, as well as manoalide 123 and secomanoalide $124 .^{88}$ Both 120 and 121 inhibited $\mathrm{PLA}_{2}$ and were anti-inflammatory agents whilst luffasterol A 122 demonstrated activity in the NCI's 60 cell line panel.

\section{Luffariella variabilis}

This sponge has a dark grey to black exterior with a cream to orange interior. It can be differentiated from other sponges of similar exterior appearance because the fibres are usually orange in color. The sponge can be massive or encrusting and has many different shapes. It is sometimes fouled by other sponges and/or tunicates and is one of the 10 most common sponges on the reefs around Palau. In 1981 it was estimated to be the third most common sponge between 10 and $20 \mathrm{~m}$ depth at the Short Drop Off. This sponge has also been reported from Guam and the Philippines.

Chemistry/bioactivity: Scheuer and coworkers ${ }^{89,90}$ reported the isolation of manoalide 123, secomanoalide 124 and $(E)$ - and $(Z)$-neomanoalides, but did not report their important anti-inflammatory activity. After examining a number of specimens of $L$. variabilis, Kernan et al. ${ }^{91}$ found that although most individuals contained manoalide and secomanoalide, some contained luffariellins A 125 and B 126 and others contained mixtures of all four compounds. Further research on L. variabilis from Palau ${ }^{92}$ resulted in the discovery of luffalactone 127 and $(4 E, 6 E)$-dehydromanoalide.

Although manoalide was first reported as an antimicrobial agent, its most important activity was as an anti-inflammatory agent. The groups of Jacobs ${ }^{93-96}$ and Dennis ${ }^{97,98}$ independently established that manoalide inhibits the enzyme phospholipase $A_{2}$, which is involved in the initial step of the inflammatory response. Since manoalide was present at a level of about $1 \%$ dry weight from a common sponge, it was regarded as a good candidate for drug development and its use as an anti-inflammatory agent was patented by the University of California. It was tested by Allergan Corp. as a topical treatment for psoriasis but the formulation used did not allow sufficient drug to pass through the skin and subsequently Allergan continued work on synthetic compounds based on the manoalide structure. All subsequent trials were not performed with the natural product.

The apparent failure of manoalide as a potential drug did not discourage additional research on details of its mechanism as a phospholipase $\mathrm{A}_{2}\left(\mathrm{PLA}_{2}\right)$ inhibitor. ${ }^{96,99-102} \mathrm{PLA}_{2}$ is the enzyme responsible for the hydrolysis of membrane-bound phospholipids to release arachidonic acid that is subsequently converted into the prostaglandins and leukotrienes that ultimately cause the pain experienced in bee stings, psoriasis, arthritis and other inflammatory conditions. It was shown that manoalide undergoes an irreversible chemical reaction with lysine<smiles>CC(=CCCC1=CC(=O)O[C@@H]1O)CCC=C(C)CCC1=C(C)CCCC1(C)C</smiles>

120<smiles>CCCCC1CCC2C(C)(CCC3C(C)(C)CCCC32C)C1CC(OC(C)=O)C1=CC(=O)O[C@@H]1O</smiles>

121<smiles>CC[C@]1(O)C(C2=CC3O[C@]34CC(OC(C)=O)CC[C@]2(C)C4=O)CCC1[C@H](C)CCCC(C)C</smiles>

122

123<smiles>CC1=C(CC/C(C)=C/CC/C(C)=C/C[C@H](O)C2=CC(=O)O[C@@H]2[OH2+])C(C)(C)CCC1</smiles> 

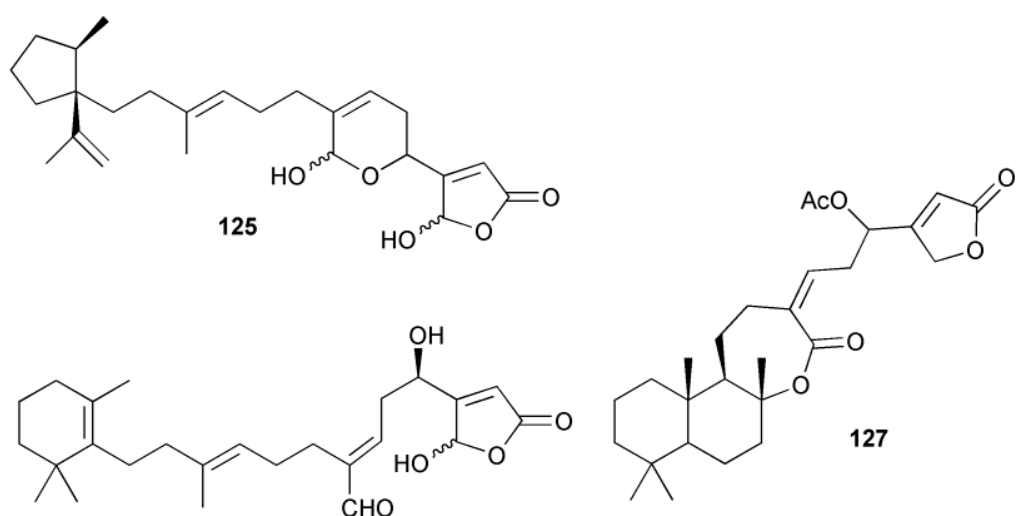

126<smiles>CC1(C)CCCC2(C)C1CCC1(C)C2CC(O)C2(C)C3C(=CCC12)C(=O)OC3O</smiles>

128

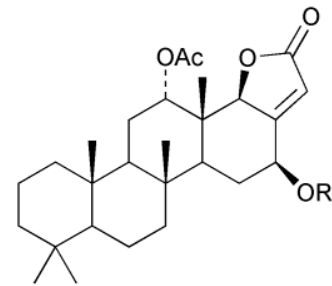

$130 ; R=H$ $131 ; R=A C$

units on the interfacial binding site on $\mathrm{PLA}_{2}$ and thus prevents the correct binding between $\mathrm{PLA}_{2}$ and membrane-bound phospholipids. $^{103}$

Manoalide is now widely used as a biochemical reagent to inhibit $\mathrm{PLA}_{2}$, although at higher concentrations it inhibits other lysine-rich enzymes. Interestingly, manoalide also reacts with the lysine residues in sponge fibers to form an orange complex that stains the fibers. The biological activity of luffariellin A 125 is identical to that of manoalide 123, while secomanoalide $\mathbf{1 2 4}$ and luffariellin B $\mathbf{1 2 6}$ are less active. A structure-activity study of manoalide and its derivatives has been reported ${ }^{104}$ together with a review of the work through 1992. ${ }^{105}$ As mentioned earlier, there are derivatives based on the manoalide pharmacophore that are still in different research phases in industry.

\section{Spongia matamata}

This specimen of $S$. matamata de Laubenfels was collected at Risong Marine Lake in 1995 and a voucher specimen was deposited in the SIO Benthic Invertebrate collection (\#P-1165).

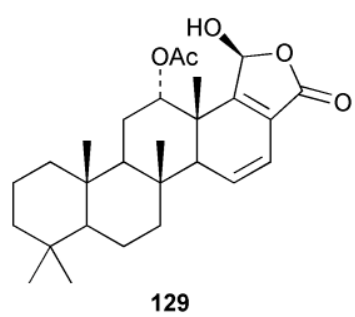<smiles>CC[C@@]1(O)[C@H](C2=CC3O[C@]34C[C@H](C)CC[C@]24C)CC[C@@H]1C(C)CCC(C)C</smiles>

Chemistry/bioactivity: S. matamata contained scalarin 128, $12 \alpha$-acetoxy-19 $\beta$-hydroxyscalara-15,17-dien-20,19-olide $\mathbf{1 2 9}$, $12 \alpha$-acetoxy-16 $\beta$-hydroxyscalarolbutenolide 130, $12 \alpha, 16 \beta$-di-

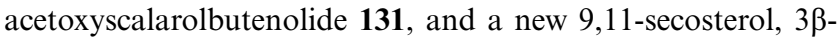
hydroxy-5 $\alpha, 6 \alpha$-epoxy-9-oxo-9, 11 -seco- $5 \alpha$-cholest-7-en-11-al 132. ${ }^{106}$ Unpublished research by Dr Robert Jacobs and coworkers (UC Santa Barbara) suggested that 129 exhibited significant anti-inflammatory activity.

\section{Thorectandra sp}

This sponge was collected in Palau by the Coral Reef Research Foundation at $10 \mathrm{~m}$ depth and a voucher specimen is held at the Smithsonian Institution (\# 0CDN5079).

Chemistry/bioactivity: the crude organic extract of this sponge demonstrated activity against breast and melanoma lines and following bioactivity-driven isolations, five new sesterterpenes, thorectandrols A-E 133-137 were reported. ${ }^{107,108}$ In addition, the known compounds luffarin R 138, luffarin V 139 and palauolide 140 and palauolol 141 were also isolated. Both 140 and 141 were shown to have $\mathrm{IC}_{50}$ values in the range of $1-100 \mu \mathrm{g} \mathrm{mL}^{-1}$ depending upon cell line. The original reports of<smiles></smiles>

133 


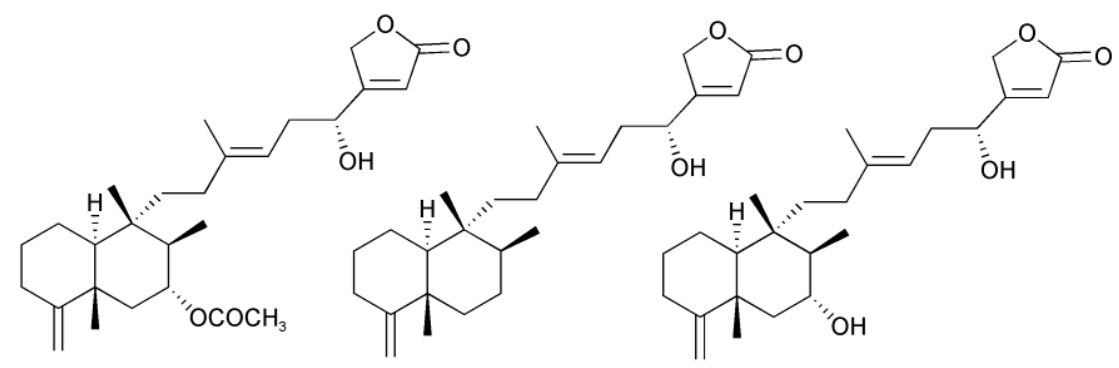

135

136

137<smiles>CC(C)=CC1C/C(=C/CC/C(C)=C/CC/C(C)=C/C[C@H](O)C2=CC(=O)OC2)C(=O)OC1/C=C(\C)CC/C=C(\C)CC/C=C(\C)CCCC1=CC(=O)OC1</smiles><smiles>C=C1CCC[C@]2(C)[C@@H](C)[C@@](C)(CC/C(C)=C/C=C/C3=CC(=O)OC3O)[C@@H]([14CH3])CC[C@]12C</smiles>

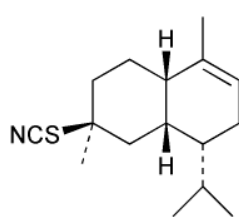

142

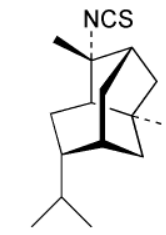

143

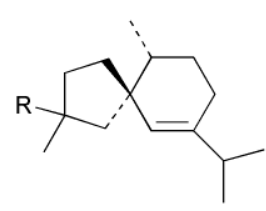

$144 ; R=N C S$

$146 ; \mathrm{R}=\mathrm{NHCHO}$

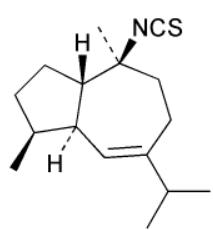

145

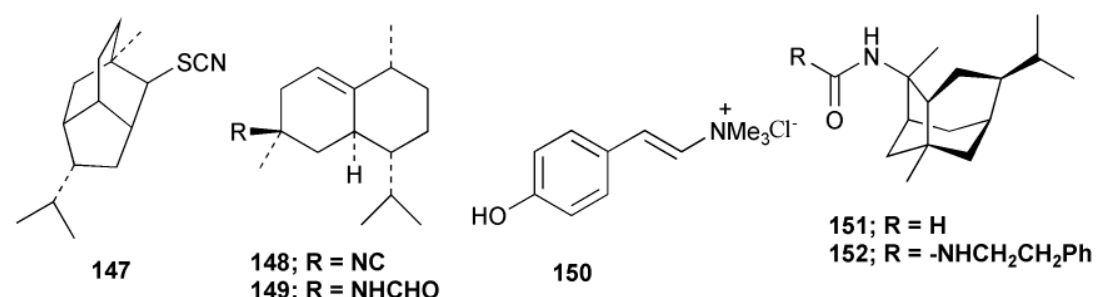

the latter two agents did not report this type of activity (vide infra).

\subsection{Porifera, Demospongiae, Halichondrida}

\section{Axinyssa aplysinoides (= Trachyopsis aplysinoides)}

This fairly common peach colored sponge was collected in and around Malakal harbor in 1985 and 1993 and was also reported from Pohnpei.

Chemistry/bioactivity: this sponge (previously called T. aplysinoides) was the source of the first naturally occurring sesquiterpene thiocyanate $\mathbf{1 4 2}$ plus three sesquiterpene isothiocyanates 143-145 and a formamide 146. ${ }^{109}$ Subsequent studies of $A$. aplysinoides uncovered another thiocyanate $147,{ }^{110}$ an isonitrile 148, a formamide 149 , a tyrosine derivative $\mathbf{1 5 0}$, two unrelated diterpenes, neoverrucosan-5 $\beta$-ol and homover- rucosan-5 $\beta$-ol ${ }^{111}$ and the formamide 151 and urea $152,{ }^{112}$ with the structures of 141 and $\mathbf{1 5 1}$ being determined by X-ray analysis. Although sesquiterpene isonitriles, formamides and isothiocyanates are believed to be feeding deterrents, no such studies with this particular group of compounds have been reported. Though the crude extract of another sample of this sponge exhibited DNA damaging activity, the active constituent(s) was/were not reported but two novel nitrogenous sesterterpenes were isolated and purified, 2-(formylamino)trachyopsane 153 and $N$-phenethyl- $N$-2-trachyopsanylurea $154 .^{112}$

\section{Halichondria cf. lendenfeldi}

Halichondria cf. lendenfeldi is a dark grey-green hispid rope sponge that was collected in a bay next to the entrance to the Ngell Channel. 


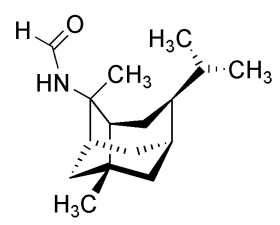

153

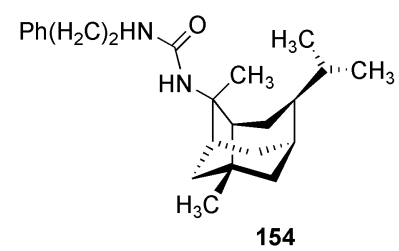

154
Chemistry/bioactivity: Halichondria cf. lendenfeldi contained two sesquiterpene isonitriles, 3-isocyanotheonellin $\mathbf{1 5 5}$ and 3-isocyanobisabolane-8,10-diene $\mathbf{1 5 6}$ and the corresponding formamides, 3-formamidotheonellin and 3-formamidobisabolane-8,10-diene. ${ }^{113}$ No bioactivity data was determined as the sponge was being studied as a possible food source for nudibranchs of the genus Phyllida.

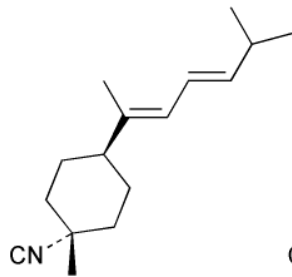

155

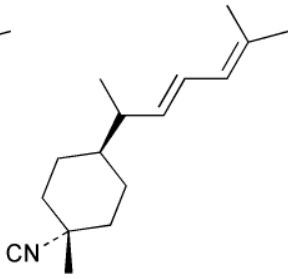

156

\section{Halichondria sp}

A black sponge of the genus Halichondria was collected in "Mini Marine Lake" on the east side of Urukthapel due south of MMDC with a voucher specimen deposited in the SIO Benthic Invertebrate Collection (\# PI 116).

Chemistry/bioactivity: this sponge contained four diterpene isonitriles, 7-isocyano-1-cycloamphilectene 157, 7-isocyano-11cycloamphilectene 158, 8-isocyano-10,14-amphilectadiene 159, and 8-isocyano-1(12)-cycloamphilectene 160, that were identified by X-ray analyses. ${ }^{114}$ As with other isonitriles, compounds 159 and 160 were mildly antimicrobial against Gram positive bacteria.

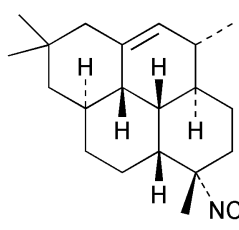

157

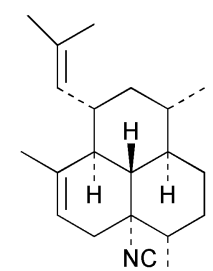

159

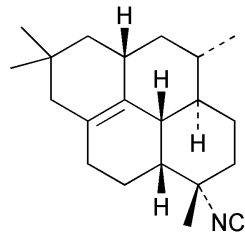

158

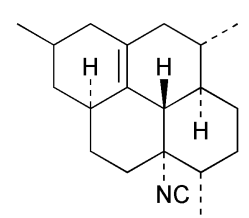

160

\section{Hymeniacidon sp}

The specimen of Hymeniacidon sp. was collected in 1979 near Long Island and after initial screening, a larger $(250 \mathrm{~kg})$ sample was collected in 1985.

Chemistry/bioactivity: the cyclic peptide hymenistatin $1 \mathbf{1 6 1}$ was obtained in very low yield after an extensive bioassay guided fractionation. ${ }^{115}$ Owing to the low yield, hymenistatin 1 was subsequently synthesized. ${ }^{116}$ The compound was isolated by following P388 activity and provided a 30\% life extension against this murine leukemia.<smiles>CCC(C)C(NC(=O)C(CC(C)C)NC(=O)C1CCCN1C(=O)[C@@H](NC(=O)[C@@H](Cc1ccc(O)cc1)NC(=O)C1CCCN1C(=O)C1CCCN1C(=O)C(C)C)C(C)CC)C(C)CC</smiles>

\section{Stylotella agminata (renamed S. aurantium, 1998)}

Specimens of S. agminata were collected in 1977 and 1991 near Wonder Channel. In 1998, this sponge was reclassified as $S$. aurantium. ${ }^{117}$

Chemistry/bioactivity: the bisguanidine alkaloid palau'amine $\mathbf{1 6 2}$ was isolated from the 1991 collection of S. agminata $^{118}$ with five additional related metabolites being reported by workers from the same group in 1998 when the taxonomy was revized. ${ }^{117}$ Palau'amine is relatively non-toxic in mice but is cytotoxic to P-388 and A549 cells. It is also antimicrobial and antifungal and showed promise in an immunomodulatory assay. It should be noted that the dust from the dried sponge caused a powerful allergic reaction in man, manifested as shortness of breath for 4 hours.

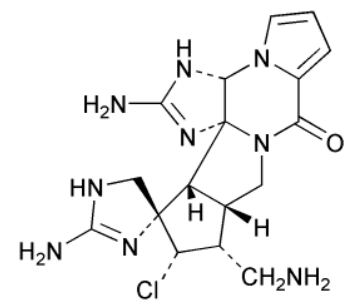

162

There have been several syntheses of this alkaloid in the past but recently, synthetic routes to palau'amine precursors via construction of the spirocyclic core, ${ }^{119}$ via formation of triazacyclopent $(c d)$-pentalenes ${ }^{120}$ or via modifications of a phakellin synthesis ${ }^{121}$ have been reported. These have the potential to construct variations on the structures by synthetic methodologies that could lead to determination of SAR characteristics.

\section{Stylotella aurantium}

This golden orange colored sponge is one of the most common sponges found in the shallow waters of the lagoon in Palau. It is illustrated in Colin and Arneson ${ }^{77}$ (entry 107).

Chemistry/bioactivity: $S$. aurantium is a good source of hymenialdisine 163 and debromohymenialdisine 164, compounds that were first described from Axinella verrucosa and Acanthella auriantica by Cimino et al., ${ }^{122}$ and also from Hymeniacidon aldis, ${ }^{123}$ and Phakellia flabellata. ${ }^{124}$ In addition, the 10E-geometrical isomers were reported as minor constituents of the sponge in $1996 .{ }^{125}$ Debromohymenialdisine (DBH)<smiles>[R]c1cc2c([nH]1)C(=O)NCC/C2=C1\NC(N)=NC1=O</smiles>

163; $\mathrm{R}=\mathrm{Br}$ $164 ; R=H$ 
has been identified as a potent anti-inflammatory agent, which led to its being patented for the treatment of rheumatoid arthritis by SmithKline Beecham (SKB, now Glaxo SmithKline) and for osteoarthritis (by OsteoArthritis Sciences Inc., now defunct) and as a protein kinase C inhibitor by SKB. At least two separate syntheses have been published. ${ }^{126,127}$

\subsection{Porifera, Demospongiae, Haplosclerida}

\section{Order Haplosclerida}

This sponge was collected by hand in 1993 at a depth of $50 \mathrm{~m}$ near the "Blue Hole" in Palau, and was identified by Dr M. Kelly(-Borges), with a voucher sample being deposited at the Natural History Museum in London (\# BMNH 1996.9.17.1).

Chemistry/bioactivity: using a bioassay for cathepsin $\mathrm{K}$ (a cysteine protease implicated as playing a role in osteoporosis), a new tryptamine derived alkaloid, haploscleridamine $\mathbf{1 6 5}$ was isolated and demonstrated activity in the assay with an $\mathrm{IC}_{50}$ value of $26 \mu \mathrm{M} .^{128}$

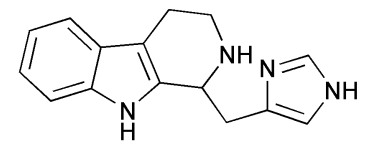

165

\section{Cribochalina olemda}

This material was collected in Palauan waters by scientists from the Suntory Institute but no physical collection data were given in the paper. Taxonomic identification was made by Dr J. Hooper of the Queensland Museum and a voucher sample (QMG306418) was deposited there.

Chemistry/bioactivity: using the aqueous extract of the sponge and following activity by inhibition of ${ }^{3} \mathrm{H}$-CGP39653 binding to $N$-methyl-D-aspartic acid (NMDA) receptors from rat brain, a novel amino acid named cribonic acid 166 that demonstrated good activity $\left(\mathrm{IC}_{50}\right.$ value of $\left.83 \mathrm{nM}\right)$ was isolated and purified. This compound was also active in vivo in mice following direct intracerebroventricular injection and gave an estimated $\mathrm{ED}_{50}$ of $29 \mathrm{pM}$ per mouse. ${ }^{129}$ What is also of interest is that the des-hydroxy compound $\mathbf{1 6 7}$ was also isolated from two non-Palauan Micronesian sponges, A. carteri and S. aurantium but was not found in the Palauan sample. This compound was almost as active as the hydroxyl analogue but what is of particular note is that this compound $\mathbf{1 6 7}$ was first reported from a phytochemical study of the legume Pletophorum africanum, ${ }^{130}$ thus the actual source of the agent may be noninvertebrate.

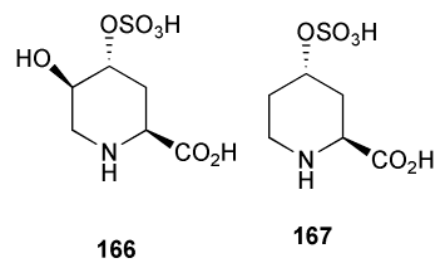

\section{Haliclona sp. (Red)}

This is a bright red encrusting sponge that is found on reef walls, especially along the south wall of Lighthouse Channel.
The sponge resembles the description of Haliclona hornelli given by Dendy in 1916, but no definitive identification has been made (van Soest, pers. comm.). There is a photograph of what is probably the same sponge in Colin and Arneson ${ }^{77}$ but there it is identified as an Adocia sp. (entry 122). In Pohnpei the same sponge apparently occurs as part of a two-sponge association with a choristid sponge.

Chemistry/bioactivity: the sponge contains good quantities of two isomeric alkaloids, haliclonadiamine 168 and papua'amine 169, which were first described from a specimen of Haliclona sp. from Papua New Guinea ${ }^{131}$ occurring in a ratio of approximately $2: 1$ in the Palauan specimen with the structure of haliclonadiamine being confirmed by X-ray crystallographic analysis of the corresponding diacetate. ${ }^{132}$ There was some confusion about the physical and spectral properties of the compounds because they can form both mono- and di-hydrochloride salts, but there have been several syntheses of these alkaloids reported. Both haliclonadiamine 168 and papua'amine 169 inhibited Candida albicans, Bacillus subtilis and Staphylococcus aureus at 1-5 $\mu$ g.disc ${ }^{-1}$. Papua'amine also demonstrated reasonably effective antifungal activity against the dermatophyte, Trichophyton mentagrophytes at $10 \mu \mathrm{g} \cdot \mathrm{disc}^{-1}$. In addition, recent work has demonstrated that papua'amine $\mathbf{1 6 9}$ caused vesiculation of the Golgi membranes (see Hippospongia metachromia) and work is still continuing on this aspect.

\section{Haliclona (aka Adocia)}

This pale lilac colored rope sponge was collected at Turtle Island basin and though originally considered to be an Adocia sp. it is now placed in the genus Haliclona.

Chemistry/bioactivity: Haliclona (aka Adocia) sp. contains six hexaprenyl hydroquinone sulfates exemplified by adociasulfates 2170 and $6 \mathbf{1 7 1}$. Adociasulfate 2 and the corresponding mono-sulfate, adociasulfate 6 , are the first known natural product inhibitors of kinesin motor proteins, which are responsible for the transport of chemicals along microtubules within the cell, ${ }^{133,134}$ with the only other published inhibitors being a synthetic small molecule from a chemical genetics program (monastrol), nucleotide analogues or organic dyestuffs. ${ }^{135}$

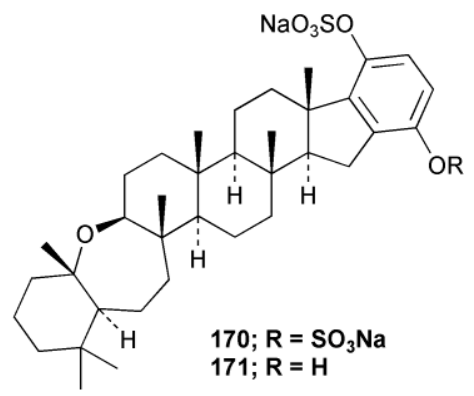

\section{Haliclona sp}

This specimen of a Haliclona sp. was collected at a depth of $18-20 \mathrm{~m}$ on the fringing reef and a voucher specimen has been deposited at the SIO Benthic Invertebrate Collection (registry \# P1160)

Chemistry/bioactivity: the Haliclona sp. contained three new acetylenes, $\quad(3 R, 4 E, 23 Z)-3$-hydroxy-11-methylhexacosa-4,23diene-1,25-diyne 172, (3Z,23Z)-methylhexacosa-3,23-diene1,25-diyne, and (3Z)-14-methyldocosa-3-en-1-yne, but no bioactivity assays were performed. ${ }^{136}$

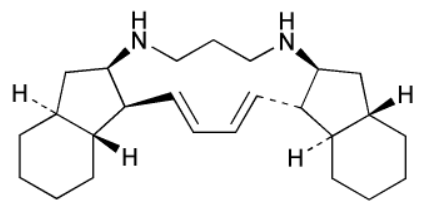

168<smiles>C/C=C\C=C\C1C(NCCCCNC2CC3CCCC[C@@H]3C2)CC2CCCC[C@H]21</smiles>

169 
<smiles>C#C/C=C\CCCC(C)CCCCC=CC(O)C#C</smiles>

172

\section{Reniera sp}

This small purple sponge was collected in 1987 from a small marine lake on Urukthapel Island, which subsequently has almost filled with silt. On further inspection it proved to be the same sponge that had previously been collected on the Pacific coast of Mexico.

Chemistry/bioactivity: the Reniera sp. from Palau contained two new alkaloids, renieramycins E 173 and F 174 which were potent antimicrobial agents but unstable. ${ }^{137}$ The base structure of these materials is very close to that of the saframycins from a terrestrial streptomycete and to safracin B from a marine pseudomonad.

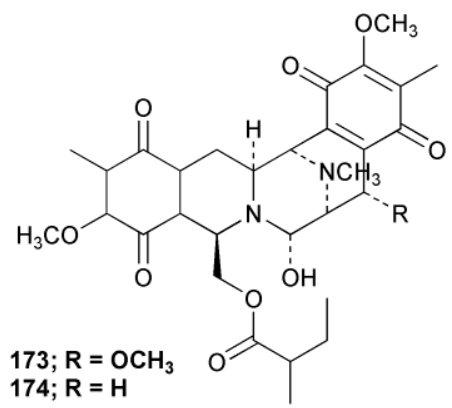

\subsection{Porifera, Demospongiae, Homosclerophorida}

\section{Plakortis aff. angulospiculatus}

Specimens of Plakortis aff., angulospiculatus were collected from a reef on the Southwestern side of Palau in 1993 and at
Siaes Tunnel in 1996. The Palauan specimens most closely resemble $P$. angulospiculatus, which is a Caribbean sponge.

Chemistry/bioactivity: both specimens of $P$. aff. agulospiculatus contained the cyclic peroxide 175 while the 1993 specimen also contained the cyclic peroxide 176, which indicated that this earlier specimen was probably contaminated with a closely related Plakortis species, which was subsequently found among the Palau collections made in 1997. In addition to these cyclic peroxides, a series of related furans was also isolated. Both peroxides inhibited the proliferation of Leishmania mexicana promastigotes with 175 having an $\mathrm{LD}_{50}$ of $0.29 \mu \mathrm{g} \mathrm{mL}^{-1}$ and peroxide 176 being approximately three-fold less effective with an $\mathrm{LD}_{50}$ of $1.00 \mu \mathrm{g} \mathrm{mL}{ }^{-1}{ }^{138}$ What may be of interest is that a number of marine-derived cyclic peroxides have been reported to demonstrate anti-malarial activity as well.

\section{Plakortis lita}

This sponge was collected off Koror Island at depths from $0-10 \mathrm{~m}$ in 1995 and 1997, being frozen following collection and maintained frozen until extracted.

Chemistry/bioactivity: the extracts yielded the known compound, plakotenin 177, its sodium salt 178, homo-plakotenin as both the free acid $\mathbf{1 7 9}$ and sodium salt $\mathbf{1 8 0}$ and the sodium salt of $n o r$-plakotenin 181. Of these five compounds, plakotenin, its sodium salt and homo-plakotenin were found to inhibit the proliferation of rheumatoid synovial fibroblasts by 36 to $77 \%$ at a concentration of $1 \mu \mathrm{g} \mathrm{mL}^{-1}$ in an assay performed at SmithKline Beecham. ${ }^{139}$

\section{Plakortis nigra}

This sponge was collected by hand in Palau at $\sim 120 \mathrm{~m}$ using a mixed gas rebreathing apparatus and was deposited in the SIO Benthic Invertebrate Collection (\# P1181). The taxonomic identification was by Dr J. Hooper of the Queensland Museum.

Chemistry/bioactivity: using activity against the human colon tumour cell line HCT-116 as the assay, eight new<smiles>CCCCC(C)C[C@]1(CC)C=C(CC)C(CC(=O)O)OO1</smiles>

175<smiles>CC/C=C/C(CC)C/C(=C/C1(CC)C[C@H](CC)C(CC(=O)O)OO1)CC</smiles>

176<smiles>[R]OC(C)=C[C@]1(CC)[C@@H](c2ccccc2)C=C(C)[C@H]2[C@H](C)C[C@H](C)[C@H]21</smiles>

$177 ; \mathrm{R}=\mathrm{H}$ $178 ; \mathrm{R}=\mathrm{Na}$<smiles>[R]OC(C)=C[C@]1(CC)[C@@H](c2ccccc2)C=C(CC)[C@H]2[C@H](C)C[C@H](C)[C@H]21</smiles>

$179 ; \mathrm{R}=\mathrm{H}$ $180 ; R=N$<smiles>[R]OC(C)=C[C@@]1(C)[C@@H](c2ccccc2)C=C(C)[C@H]2[C@H](C)C[C@H](C)[C@H]21</smiles>

$181 ; \mathrm{R}=\mathrm{Na}$<smiles>C=Cc1nccc2c1[nH]c1cc(Br)ccc12</smiles>

182

183<smiles>CN(CCc1nccc2c1[nH]c1cc(Br)ccc12)CCc1nccc2c1[nH]c1cc(Br)ccc12</smiles>

184<smiles>CN1CCC(c2nccc3c2[nH]c2cc(Br)ccc23)O1</smiles> 
compounds were isolated and purified, of which the first seven demonstrated activities in the $0.4-15 \mu \mathrm{M}$ range for $\mathrm{IC}_{50}$ values. ${ }^{140}$ The compounds were plakortamines A-D 182-185, epiplakinic acids $\mathrm{G} 186$ and $\mathrm{H} \mathbf{1 8 7}$ and two related $\gamma$-lactones, $\left(2 S^{*}, 4 R^{*}\right)$-2,4-dimethyl-4-hydroxy-16-phenylhexadecanoic acid 1,4-lactone 188 and $\left(2 R^{*}, 4 R^{*}\right)$-2,4-dimethyl-4-hydroxy-16phenylhexadecanoic acid 1,4-lactone $\mathbf{1 8 9}$.<smiles>CC(CCCCCCCCc1ccccc1)CC(C)C[C@]1(C)CC(C)(CC(=O)O)OO1</smiles><smiles>CC1(CCCCCCCCCCCc2ccccc2)CC(C)(CC(=O)O)OO1</smiles>

187

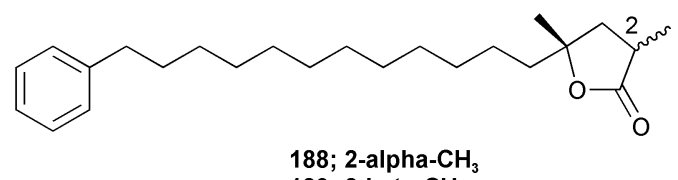
189; 2-beta- $\mathrm{CH}_{3}$

\subsection{Porifera, Demospongiae, Lithistida}

\section{Theonella swinhoei}

Specimens of $T$. swinhoei were collected at depths of $20-30 \mathrm{~m}$ on the inside of Babelukes Reef and a representative photograph is shown in Colin and Arneson (entry 46). ${ }^{77}$

Chemistry/bioactivity: the Palauan T swinhoei contains theonellasterol 190, ${ }^{141}$ the cytotoxic macrolide swinholide A 191, and the cyclic peptide theopalauamide 192. ${ }^{142}$ Swinholide A was reported to demonstrate strong antitumour activity ${ }^{143}$ whilst theopalauamide demonstrated antifungal activity.

Symbiosis studies: using novel techniques including fixation of the sponge cellular contents and subsequent HPLC and NMR studies on the isolated cells, Bewley et al. ${ }^{3}$ demonstrated that both 191 and 192 were shown to be associated with symbiotic unicellular bacteria and filamentous fungi, respectively. Identification of the microbes has not been formally reported as yet.

\subsection{Porifera, Demospongiae, Petrosida}

\section{Oceanapia saggitaria}

A specimen of $O$. sagittaria was collected in relatively shallow water at Ngeruktebel Marine Lake in 1995 and has been deposited in the SIO Benthic Invertebrate Collection (P1163).

Chemistry/bioactivity: the major metabolite of $O$. sagittaria is dercitamide 193, which was first isolated from a deep-water sample of a Stelletta sp. ${ }^{144}$ and also from a tunicate of the genus Cystodytes. ${ }^{145}$ In addition to dercitamide, whilst working on the cellular location of that compound, the minor metabolite sagitol 194 was isolated and identified. ${ }^{146}$ Dercitamide was reported to be a cytotoxic and immunosuppressive agent ${ }^{144}$ and very similar compounds of the same pyridoacridine class were<smiles>C=C1[C@H](O)CC[C@]2(C)C3CCC4=C5CCC(C(C)CCC(CC)C(C)C)[C@@]5(C)CC[C@H]4C3CCC12C</smiles>

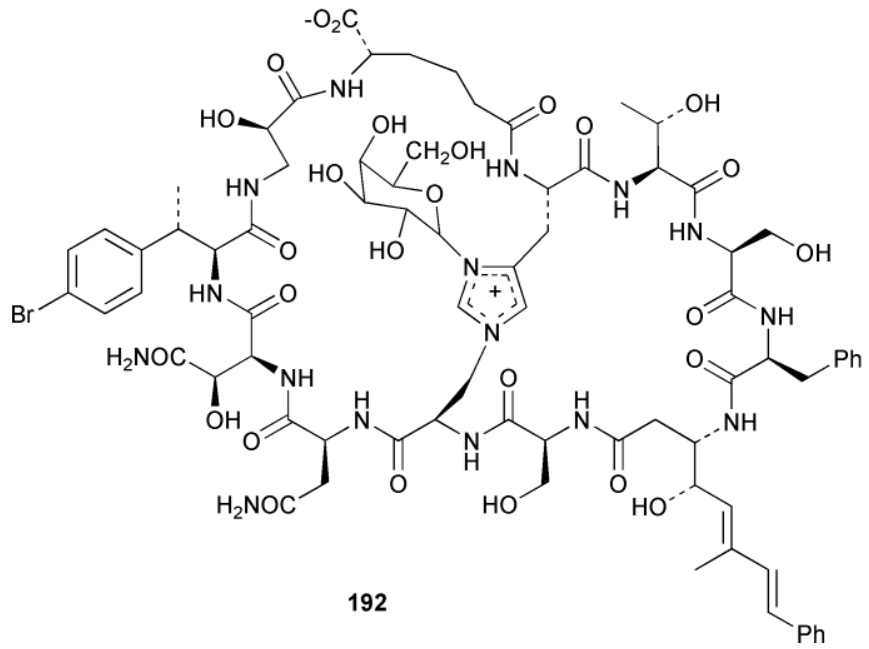


<smiles>CCOC(=O)NCCc1c2c3c(ccnc3c3ncsc13)-c1ccccc1N2</smiles>

193

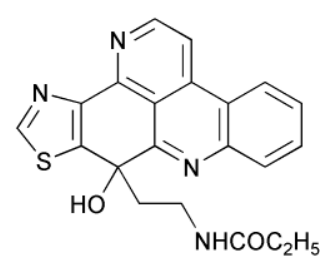

194 found to be topoisomerase II inhibitors. In contrast, sagitol was inactive in cytotoxicity assays.

Cellular location studies: since dercitamide (also known as kuanoniamine C) was found in both sponges and ascidians, it had been proposed that the compound was produced by a symbiotic microorganism. Studies using confocal microscopy to detect the natural fluorescence of $\mathbf{1 9 3}$, following cell separation techniques and chemical analysis, showed that it was localized exclusively in bacteria-free sponge inclusional cells, and was probably not produced by extracellular bacteria and then transferred to the sponge cells. ${ }^{4}$

Finally, there is a recent paper by Skyler and Heathcock describing the "Family Tree" of the pyridinoacridine metabolites that should be consulted for its predictions as to as yet undiscovered/unsynthesized compounds of this general structural class. ${ }^{147}$

\section{Siphonodictyon sp}

Siphonodictyon sp. is a white colored sponge that burrows into live coral heads leaving only the oscular chimney protruding. It is not very common and was occasionally found on the western fringing reef of Palau.

Chemistry/bioactivity: this Siphonodictyon sp. contained relatively large amounts of siphonodictidine 195, an unusual guanidinosesquiterpene that inhibits photosynthesis and respiration in Acropora formosa causing death of the coral polyps. ${ }^{148}$ The siphonodictidine appears to be released in a mucous secretion that inhibits the growth of coral polyps around the oscular chimney.

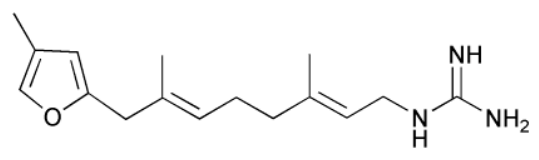

195

\section{Xestospongia exigua}

Xestospongia exigua was collected in 1977 and 1981 by members of the Scheuer group and was identified by Bergquist, but no details of the collection are currently available.

Chemistry/bioactivity: the structure of halenaquinone 196 was determined by single crystal X-ray analysis, ${ }^{149}$ and the compound exhibited modest in vitro activity versus $S$. aureus and $B$. subtilis.<smiles>CC12CCC(=O)c3coc(c31)C(=O)c1cc3c(cc12)C(=O)C=CC3=O</smiles>

196

\section{Xestospongia sp}

This specimen of Xestospongia sp. was collected in 1995 at a depth of $20 \mathrm{~m}$ from the fringing reef at Palau and a voucher was deposited in the SIO Benthic Invertebrate Collection (P-1168).

Chemistry/bioactivity: the major metabolite isolated from this sponge was araguspongine C 197, which had previously been described from an Okinawan specimen of Xestospongia sp. by Kobayashi et al. ${ }^{150}$ who reported that it exhibited vasodilative properties in an isolated rat artery model, together with a new minor metabolite, $3 \beta, 3 \beta^{\prime}$-dimethylxestospongine $\mathrm{C} \mathbf{1 9 8}{ }^{151}$

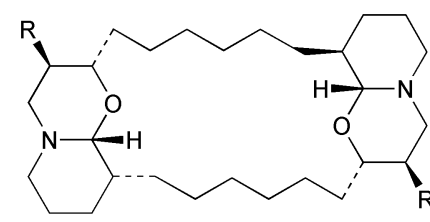

197; R = H

198; $\mathrm{R}=\mathrm{CH}_{3}$

\subsection{Porifera, Demospongiae, Poecilosclerida}

\section{Damiria sp}

This black encrusting sponge, which was collected at Ngemelis drop-off at a depth of $20 \mathrm{~m}$, has since been reclassified as Zyzzya fuliginosa. ${ }^{152}$

Chemistry/Bioactivity: two pyrroloquinones, damirones A 199 and $\mathrm{B}$, were isolated from this sponge but no bioactivity was reported.<smiles>CN1CCC2CN(C)C3=C2C1=CC3=O</smiles>

199

\subsection{Porifera, Demospongiae, Verongida}

\section{Fascaplysinopsis $\mathbf{s p}$}

This sponge was collected at Ngemelis drop-off in 1995 and is probably the same sponge that was studied in 1980 from a R/V Alpha Helix cruise where many sponge samples were combined due to a freezer failure.

Chemistry/bioactivity: a compound called palauolide 140 was obtained from the 1980 (mixed) collection of sponges. ${ }^{153}$ In contrast, from the 1985 collection palauolol 141 was found to be the major metabolite of the of Fascaplysinopsis sp. and was shown to dehydrate to obtain palauolide. ${ }^{154}$ This sample also contained the known metabolite fascaplysin 200, which had been reported in 1988 from a Fijian collection of Fascaplysinopsis reticulata. ${ }^{155}$ Both 140 and 141 inhibit phospholipase $\mathrm{A}_{2}$ and antimicrobial activity was reported for $\mathbf{1 4 0}$ and $\mathbf{2 0 0 .}$

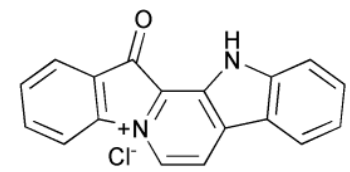

200

\section{Conclusion}

The work that is presented above is just an example of the chemical, biochemical, microbiological and marine biological riches that are present in one atoll in the Central South Pacific Ocean. As a result of the geographic location and the ease of access, together with the support of the Government of the Republic of Belau, scientists have been permitted to investigate the waters of this country. 
Due to the presence of the NCI's shallow water collection contractor, the Coral Reef Research Foundation in Palau for the last 10 years, Palau has what is probably the best inventory of taxonomically identified marine fauna of any country when expressed on a square kilometre basis. Even with that, there are still immense areas that have not been investigated, particularly in the microbial environment.

One has only to look at the vastly different chemical entities that have been found from what is effectively less than 3 kilograms of cyanophytes (cf Lyngbya and Symploca above), to realize the immensity of the scientific investigations yet to come and the potential for discovery of novel pharmaceutical agents and biological probes is definitely proven by the work listed above.

The Government of Belau is justifiably reticent in awarding research collection permits to non-citizens for such studies and it was one of John's proudest accomplishments that he held one of the first permits awarded. The foresight of the Government of Belau in giving John such a collection permit is amply demonstrated by the extensive investigations performed by his group over the period 1979-2002 as shown in this review.

This work will be continued both by his students from over the years and by others at Scripps and other universities/institutions, who, like John, have the best interests of Palau at heart, as any samples from their collections that may ultimately be commercialized will have as part of any development programme, a requirement that Palau must benefit.

\section{References}

1 M. Etpison, Palau, Portrait of Paradise, NECO Marine Corp., Palau, 1997.

2 J. N. A. Hooper, J. A. Kennedy and R. J. Quinn, Biodiv. Conserv, 2002, 11, 851

3 C. A. Bewley, N. D. Holland and D. J. Faulkner, Experientia, 1996, $\mathbf{5 2 ,} 716$.

4 C. E. Salomon, T. Deerinck, M. H. Ellisman and D. J. Faulkner, Mar. Biol., 2001, 139, 313

5 C. E. Salomon and D. J. Faulkner, J. Nat. Prod., 2002, 65, 689

6 X. Fu, M. L. G. Ferreira and F. J. Schmitz, J. Nat. Prod., 1999, 62, 1306.

7 C. J. Smith, D. A. Venables, C. M. Ireland, C. Hopmann, C. E. Salomon, D. J. Faulkner, J. Jompa and A. Tahir, J. Nat. Prod., 1997, 60, 1048.

8 P. W. Ford and B. S. Davidson, J. Nat. Prod., 1997, 60, 1051

9 B. C. M. Potts, D. J. Faulkner, J. A. Chan, G. C. Simolike, P. Offen, M. Hemling and T. A. Francis, J. Am. Chem. Soc., 1991, 113, 6321.

10 J. Pika and D. J. Faulkner, Nat. Prod. Lett., 1995, 7, 291

11 X. Fan, G. R. Flentke and D. H. Rich, J. Am. Chem. Soc., 1998, 120, 8893.

12 M. A. Rashid, K. R. Gustafson and M. R. Boyd, J. Nat. Prod., 2001 , 64, 1454 .

13 M. L. Dionisio-Sese, M. Ishikura, T. Maruyama and S. Miyachi, Mar. Biol., 1997, 128, 455.

14 C. Ireland and P. J. Scheuer, J. Am. Chem. Soc., 1980, 102, 5688.

15 C. M. Ireland, A. D. Durso, Jr., R. A. Newman and M. P. Hacker, J. Org. Chem., 1982, 47, 1807.

16 A. D. Patil, A. J. Freyer, L. Killmer, C. Chambers and R. K. Johnson, Nat. Prod. Lett., 1997, 9, 181.

17 J. M. Wasylyk, J. E. Biskupiak, C. E. Costello and C. M. Ireland, J. Org. Chem., 1983, 48, 4445.

18 D. F. Sesin, S. J. Gaskell and C. M. Ireland, Bull. Soc. Chim. Belg., 1986, 95, 853 .

19 C. Hopmann and D. J. Faulkner, Tetrahedron Lett., 1997, 38, 169.

20 Q. Lu and D. J. Faulkner, Nat. Prod. Lett., 1997, 10, 231.

21 A. Sato, W. Fenical, Q. Zheng and J. Clardy, Tetrahedron Lett., 1985, 41, 4303 .

22 B. F. Bowden, J. C. Coll, S. J. Mitchell, J. Mulden and G. J. Stokie, Aust. J. Chem., 1978, 31, 2049.

23 B. F. Bowden, J. C. Coll and A. D. Wright, Aust. J. Chem., 1989, 42, 757.

24 B. F. Bowden, J. C. Coll, E. D. de Silva, M. S. L. de Costa, P. J. Djura, M. Mahendran and D. M. Tapiolas, Aust. J. Chem., 1983, 36, 371

25 S. Mizobuchi, K. Kon-ya, K. Adachi, M. Sakai and W. Miki, Fish. Sci. 1994, 60, 345.

26 S. Mizobuchi, K. Adachi and W. Miki, Fish. Sci., 1996, 62, 98.
27 S. S. Mitchell, D. J. Faulkner, K. Rubins and F. D. Bushman, J. Nat. Prod., 2000, 63, 279.

28 H. Luesch, W. Y. Yoshida, R. E. Moore and V. J. Paul, Bioorg. Med. Chem., 2002, 10, 1973.

29 H. Luesch, P. G. Williams, W. Y. Yoshida, R. E. Moore and V. J. Paul, J. Nat. Prod., 2002, 65, 996.

30 H. Luesch, W. Y. Yoshida, G. G. Harrigan, J. P. Doom, R. E. Moore and V. J. Paul, J. Nat. Prod., 2002, 65, 1945.

$31 \mathrm{H}$. Luesch, W. Y. Yoshida, R. E. Moore and V. J. Paul, Tetrahedron, 2002, 56, 7959 .

32 H. Sone, T. Kondo, M. Kiryu, H. Ishiwata, M. Ojika and K. Yamada, J. Org. Chem., 1995, 60, 4774.

33 P. G. Williams, W. Y. Yoshida, R. E. Moore and V. J. Paul, J. Nat. Prod., 2002, 65, 1336.

34 P. G. Williams, W. Y. Yoshida, R. E. Moore and V. J. Paul, J. Nat. Prod., 2003, 66, 1006.

35 P. G. Williams, W. Y. Yoshida, R. E. Moore and V. J. Paul, J. Nat. Prod., 2003, 66, 620.

36 N. Imamura, M. Nishijima, T. Takadera, K. Adachi, M. Sakai and H. Sano, J. Antibiot., 1997, 50, 8 .

37 K. Yoshikawa, T. Takadera, K. Adachi, M. Nishijima and H. Sano, J. Antibiot., 1997, 50, 949.

38 M. Namikoshi, K. Akano, S. Meguro, I. Kasuga, Y. Mine, T. Takahashi and H. Kobayashi, J. Nat. Prod., 2001, 64, 396.

39 M. Suzuki, Y. Nakagawa, S. Harayama and S. Yamamoto, Int. J. Syst. Evol. Microbiol., 2001, 51, 1639.

40 R. J. Andersen, D. J. Faulkner, C.-h. He, G. D. Van Duyne and J. Clardy, J. Am. Chem. Soc., 1985, 107, 5492.

41 B. Carte, M. R. Kernan, E. B. Barrabee, D. J. Faulkner, G. K. Matsumoto and J. Clardy, J. Org. Chem., 1986, 51, 3528.

42 M. R. Kernan, E. B. Barrabee and D. J. Faulkner, Comp. Biochem. Physiol., B: Biochem. Mol. Biol., 1988, 89, 275.

43 M. Nakagawa, Y. Hamamoto, M. lshihama, S. Hamasaki and M. Endo, Tetrahedron Lett., 1987, 28, 431.

44 R. Kazlauskas, P. T. Murphy and R. J. Wells, Aust. J. Chem., 1982, 35,51 .

45 J. C. Braekman, D. Daloze, C. Soller and R. W. M. Van Soest, Biochem. Syst. Ecol., 1992, 20, 417.

46 R. J. Capon and D. J. Faulkner, J. Am. Chem. Soc., 1984, 106, 1819.

47 L. Kitagawa, M. Kobayashi, Y. Okamoto, M. Yoshikawa and Y. Hamamoto, Chem. Pharm. Bull., 1987, 35, 5036

48 M. Kobayashi, Y. Okamoto and I. Kitagawa, Chem. Pharm. Bull., 1991, 39, 2867.

49 T. M. Zabriskie, J. A. Klocke, C. M. Ireland, A. H. Marcus, T. F. Molinski, D. J. Faulkner, C. Xu and J. Clardy, J. Am. Chem. Soc., 1986, 108, 3123

50 P. Crews, L. V. Manes and M. Boehler, Tetrahedron Lett., 1986, 27, 2797.

51 A. Zampella, C. Giannini, C. Debitus, C. Roussakis and M. V. D'Auria, J. Nat. Prod., 1999, 62, 332.

52 M. R. Bubb, A. M. Senderowicz, E. A. Sausville, K. L. Duncan and E. D. Korn, J. Biol. Chem., 1994, 269, 14869.

53 A. M. Senderowicz, G. Kaur, E. Sainz, C. Laing, W. D. Inman, J. Rodriguez, P. Crews, L. Malspeis and M. R. Grever, J. Nat. Can. Inst., 1995, 87, 46.

54 W. R. Chan, W. F. Tinto, P. S. Manchand and L. J. Todaro, J. Org. Chem., 1987, 52, 3091.

55 J. E. Coleman, R. W. M. Van Soest and R. J. Andersen, J. Nat. Prod., $1999,62,1137$.

56 B. Kunze, R. Jansen, F. Sasse, G. Hofle and H. Reichenbach, J. Antibiot., 1995, 48, 1262.

57 F. Sasse, B. Kunze, T. M. A. Gronewold and H. Reichenbach, J. Nat. Can. Inst., 1998, 90, 1559

58 G. R. Pettit, C. L. Herald, J. E. Leet, R. Gupta, D. E. Schaufelberger, R. B. Bates, P. J. Clelow, D. L. Doubek, K. P. Manfredi, K. Riltzler, J. M. Schmidt, L. P. Tackett, F. B. Ward, M. Bruck and F. Camou, Can. J. Chem., 1990, 68, 1621.

59 G. R. Pettit, C. L. Herald, M. R. Boyd, J. E. Leet, C. Dufresne, D. L. Doubek, J. M. Schmidt, R. L. Cemy, J. N. A. Hooper and K. Riltzler, J. Med. Chem., 1991, 34, 3339.

60 G. R. Pettit, F. Gao, R. L. Cerny, D. L. Doubek, L. P. Tackett, J. M. Schmidt and J.-C. Chapius, J. Med. Chem., 1994, 37, 1165.

61 G. R. Pettit, J. W. Holman and G. M. Boland, J. Chem. Soc., Perkin Trans. 1, 1996, 2411.

62 O. Mechnich and H. Kessler, Tetrahedron Lett., 1996, 37, 5355.

63 C. M. Cerda-Garcia-Rojas and D. J. Faulkner, Tetrahedron Lett., 1995, 51, 1087.

64 S. C. Bobzin and D. J. Faulkner, J. Org. Chem., 1991, 56, 4403.

65 R. Walker and D. Faulkner, J. Org. Chem., 1981, 46, 1098.

66 J. E. Hocklowski, D. J. Faulkner, G. K. Matsumoto and J. Clardy, J. Org. Chem., 1983, 48, 1141

67 B. Sullivan and D. J. Faulkner, J. Org. Chem., 1984, 49, 3204. 
68 T. F. Molinski, D. J. Faulkner, H. Cun-heng, G. D. Van Duyne and J. Clardy, J. Org. Chem., 1986, 51, 4564.

69 S. C. Bobzin and D. J. Faulkner, J. Org. Chem., 1989, 54, 5727.

70 M. R. Kernan and D. J. Faulkner, J. Org. Chem., 1988, 53, 4574

71 G. Liu, J. Pika and D. J. Faulkner, Nat. Prod. Lett., 1995, 7, 297.

72 L. V. Manes, P. Crews, M. R. Kernan, D. J. Faulkner, F. R. Fronczek and R. D. Gandour, J. Org. Chem., 1988, 53, 570.

73 J. Kimura, E. Ishizuka, Y. Nakao, W. Y. Yoshida, P. J. Scheuer and M. Kelly-Borges, J. Nat. Prod., 1998, 61, 248.

74 H. Nakamura, S. Deng, J. Kobayashi, Y. Ohizumi and Y. Hirata, Tetrahedron Lett., 1986, 42, 4197.

75 D. M. Kushlan, D. J. Faulkner, L. Parkanyi and J. Clardy, Tetrahedron Lett., 1989, 45, 3307.

76 B. Carte and D. J. Faulkner, Tetrahedron Lett., 1981, 37, 2335.

77 P. L. Colin and C. Arneson, Tropical Pacific Invertebrates, Coral Reef Press, Beverly Hills, 1995.

78 G. M. Sharma and B. Vig, Tetrahedron Lett., 1972, 1715.

79 M. D. Unson, C. B. Rose, D. J. Faulkner, L. S. Brinen, J. Rios Steiner and J. Clardy, J. Org. Chem., 1993, 58, 6336.

80 M. D. Unson, N. D. Holland and D. J. Faulkner, Mar. Biol., 1994, 119,1 .

81 B. Carte, S. Mong, B. Poehland, H. Sarau, J. W. Westley and D. J. Faulkner, Tetrahedron Lett., 1989, 30, 2725.

82 Q. Lu and D. J. Faulkner, J. Nat. Prod., 1998, 61, 1096.

83 B. Carte, C. B. Rose and D. J. Faulkner, J. Org. Chem., 1985, 50, 2785.

84 R. T. Luibrand, T. R. Erdman, J. J. Vollmer, P. J. Scheuer, J. Finer and J. Clardy, Tetrahedron Lett., 1979, 35, 609.

85 P. A. Takizawa, J. K. Yucel, B. Viet, D. J. Faulkner, T. Deerinck, G. Soto, M. Ellisman and V. Malhotra, Cell, 1993, 73, 1079.

86 K. F. Albizati, T. Holman, D. J. Faulkner, K. B. Glaser and R. S. Jacobs, Experientia, 1987, 43, 949.

87 M. R. Kernan, D. J. Faulkner, L. Parkanyi, J. Clardy, M. S. de Carvalho and R. S. Jacobs, Experientia, 1989, 45, 388.

88 M. V. R. Reddy, M. K. Harper and D. J. Faulkner, J. Nat. Prod., 1997, 60, 41.

89 E. D. de Silva and P. J. Scheuer, Tetrahedron Lett., 1980, 21, 1611.

90 E. D. de Silva and P. J. Scheuer, Tetrahedron Lett., 1980, 21, 3147.

91 M. R. Kernan, D. J. Faulkner and R. S. Jacobs, J. Org. Chem. 1987, 52, 3081

92 B. C. M. Potts, R. J. Capon and D. J. Faulkner, J. Org. Chem., 1992, 57, 2965.

93 J. C. de Freitas, L. A. Blankmeier and R. S. Jacobs, Experientia, 1984, 40, 864.

94 R. S. Jacobs, P. Culver, R. Langdon, T. O'Brien and S. White, Tetrahedron Lett., 1985, 41, 981.

95 K. B. Glaser and R. S. Jacobs, Biochem. Pharmacol., 1986, 35, 449

96 K. B. Glaser and R. S. Jacobs, Biochem. Pharmacol., 1987, 36, 2079.

97 D. Lombardo and E. A. Dennis, J. Biol. Chem., 1985, 260, 7234

98 R. A. Deems, D. Lombardo, B. P. Morgan, E. D. Mihelich and E. A. Dennis, Biochem. Biophys. Acta, 1987, 917, 258.

99 C. F. Bennett, S. Mong, M. A. Clarke, L. I. Kruse and S. T. Crooke, Biochem. Pharmacol., 1987, 36, 733.

100 P. B. Jacobson, L. A. Marshall, A. Sung and R. S. Jacobs, Biochem. Pharmacol., 1990, 39, 1557.

101 L. J. Reynolds, E. D. Mihelich and E. A. Dennis, J. Biol. Chem., 1991, 266, 16512

102 A. R. Ortiz, M. T. Pisabarro and F. Gago, J. Med. Chem., 1993, 36, 1866 .

103 B. C. M. Potts, D. J. Faulkner, M. S. de Carvahlo and R. S. Jacobs, J. Am. Chem. Soc., 1992, 114, 5093.

104 K. B. Glaser, M. S. de Carvalho, R. S. Jacobs, M. R. Kernan and D. J. Faulkner, Mol. Pharmacol., 1989, 36, 782.

105 B. C. M. Potts, D. J. Faulkner and R. S. Jacobs, J. Nat. Prod., 1992, $\mathbf{5 5}, 1701$.

106 Q. Lu and D. J. Faulkner, J. Nat. Prod., 1997, 60, 195.

107 R. D. Charan, T. C. McKee and M. R. Boyd, J. Nat. Prod., 2001, 64, 661 .

108 R. D. Charan, T. C. McKee and M. R. Boyd, J. Nat. Prod., 2002, 65, 492 .

109 H. He, D. J. Faulkner, J. S. Shumsky, K. Hong and J. Clardy, J. Org Chem., 1989, 54, 2511.

110 H. He, J. Salvo, R. F. Catalos and D. J. Faulkner, J. Org. Chem., 1992, 57, 3191

111 R. S. Compagnone and D. J. Faulkner, J. Nat. Prod., 1995, 58, 145.

112 A. D. Patil, A. J. Freyer, R. Reichwein, M. F. Bean, L. Faucette, R. K. Johnson, R. C. Haltiwanger and D. S. Eggleston, J. Nat. Prod., 1997, 60, 507.

113 K. E. Kassuhlke, C. M. Potts and D. J. Faulkner, J. Org. Chem., 1991, 56, 3747.
114 T. F. Molinski, D. J. Faulkner, G. D. Van Duyne and J. Clardy, J. Org. Chem., 1987, 52, 3334

115 G. R. Pettit, P. J. Clewlow, C. Dufresne, D. J. Doubek, R. L. Cerny and K. Ratzler, Can. J. Chem., 1990, 68, 708.

116 R. K. Konat, D. F. Mierke, H. Kessler, B. Kutscher, M. Bernd and R. Voegeli, Helv. Chim. Acta, 1993, 76, 1649.

117 R. B. Kinnel, H.-P. Gehrken, R. Swali, G. Skoropowski and P. J. Scheuer, J. Org. Chem., 1998, 63, 3281.

118 R. B. Kinnel, H.-P. Gehrken and P. J. Scheuer, J. Am. Chem. Soc., 1993, 115, 3376.

119 A. S. Dilley and D. Romo, Org. Lett., 2001, 3, 1535.

120 G. Belanger, F.-T. Hong, L. E. Overman, B. N. Rogers, J. E. Tellew and W. C. Trenkle, J. Org. Chem., 2002, 67, 7880.

121 K. G. Poullennec and D. Romo, J. Am. Chem. Soc., 2003, 125, 6344.

122 G. Cimino, S. De Rosa, S. De Stefano, L. Mazzarella, R. Puliti and G. Sodano, Tetrahedron Lett., 1982, 23, 767.

123 I. Kitagawa, M. Kobayashi, K. Kitanaka, M. Kido and Y. Kyogoku, Chem. Pharm. Bull., 1983, 31, 2321.

124 G. W. Sharma, J. S. Buyer and M. W. Pomerantz, J. Chem. Soc., Chem. Commun., 1980, 435.

125 D. H. Williams and D. J. Faulkner, Nat. Prod. Lett., 1996, 9, 57.

126 H. Annoura and T. Tatsuoka, Tetrahedron Lett., 1995, 36, 413.

127 Y. Xu, K. Yakushijin and D. A. Home, J. Org. Chem., 1997, 62, 456.

128 A. D. Patil, A. J. Freyer, B. Carte, P. B. Taylor, R. K. Johnson and D. J. Faulkner, J. Nat. Prod., 2002, 65, 628.

129 R. Sakai, H. Matsubara, K. Shimamoto, M. Jimbo, H. Kamiya and M. Namikoshi, J. Nat. Prod., 2003, 66, 784.

130 S. V. Evans, T. K. M. Shing, R. T. Aplin, L. E. Fellows and G. W. J. Fleet, Phytochemistry, 1985, 24, 2593.

131 B. J. Baker, P. J. Scheuer and J. N. Shoolery, J. Am. Chem. Soc., 1988, 110, 965.

132 E. Fahy, T. F. Molinski, M. K. Harper, B. W. Sullivan, D. J. Faulkner, L. Parkanyi and J. Clardy, Tetrahedron Lett., 1988, 29, 3427.

133 C. L. Blackburn, C. Hopmann, R. Sakowicz, M. S. Berdelis, L. S. B. Goldstein and D. J. Faulkner, J. Org. Chem., 1999, 64, 5564.

134 R. Sakowicz, M. S. Berdelis, K. Ray, C. L. Blackburn, C. Hopmann, D. J. Faulkner and L. S. B. Goldstein, Science, 1998, 280, 292.

135 D. J. Newman, G. M. Cragg, S. Holbeck and E. A. Sausville, Curr. Cancer Drug Targs., 2002, 2, 279.

136 D. H. Williams and D. J. Faulkner, J. Nat. Prod., 1996, 59, 1099.

137 H. He and D. J. Faulkner, J. Org. Chem., 1989, 54, 5822.

138 R. S. Compagnone, I. C. Pisa, H. R. Rangel, F. Dagger, A. I. Suarez, M. V. R. Reddy and D. J. Faulkner, Tetrahedron Lett., 1998, 54, 3057.

139 A. Qureshi, C. S. Stevenson, C. A. Albert, R. S. Jacobs and D. J. Faulkner, J. Nat. Prod., 1999, 62, 1205.

140 J. S. Sandler, P. L. Colin, J. N. A. Hooper and D. J. Faulkner, J. Nat. Prod., 2002, 65, 1256.

141 E. Kho, D. K. Imagawa, M. Rohmer, Y. Kashman and C. Djerassi, J. Org. Chem., 1981, 46, 1836.

142 E. W. Schmidt, C. A. Bewley and D. J. Faulkner, J. Org. Chem., 1998, 63, 1254.

143 M. Kobayashi, K. Kawazoe, T. Okamoto, T. Sasaki and I. Kitagawa, Chem. Pharm. Bull., 1994, 42, 19.

144 G. P. Gunawardana, S. Khomoto and N. S. Burres, Tetrahedron Lett., 1989, 30, 4359.

145 G. P. Gunawardana, F. E. Koehn, A. Y. Lee, J. Clardy, H. He and D. J. Faulkner, J. Org. Chem., 1992, 57, 1523.

146 C. E. Salomon and D. J. Faulkner, Tetrahedron Lett., 1996, 37, 9147.

147 D. Skyler and C. H. Heathcock, J. Nat. Prod., 2002, 65, 1573 ,

148 B. Sullivan, D. J. Faulkner and L. Webb, Science, 1983, 221, 1175 .

149 D. M. Roll, P. J. Scheuer, G. K. Matsumoto and J. Clardy, J. Am. Chem. Soc., 1983, 105, 6177.

150 M. Kobayashi, K. Kawazoe and I. Kitagawa, Chem. Pharm. Bull., 1989, 37, 1676

151 M. V. R. Reddy and D. J. Faulkner, Nat. Prod. Lett., 1997, 11, 53.

152 R. W. M. van Soest, S. Zea and M. Kielman, Bijdragen Dierkunde, 1994, 64, 163.

153 B. Sullivan and D. J. Faulkner, Tetrahedron Lett., 1982, 23, 907.

154 E. W. Schmidt and D. J. Faulkner, Tetrahedron Lett., 1996, 37, 3951.

155 D. M. Roll, C. M. Ireland, H. S. M. Lu and J. Clardy, J. Org. Chem., 1988, 53, 3276. 